\title{
Multi-proxy survey of open-air surface scatters in drylands: Archaeological and physico-chemical characterisation of fossilised dunes in North Gujarat (India)
}

\author{
Francesc C. Conesa ${ }^{\mathrm{a}, *}$, Agustin Lobo ${ }^{\mathrm{b}}$, Jonàs Alcaina ${ }^{\mathrm{c}}$, Andrea Balbo ${ }^{\mathrm{d}}$, Marco Madella ${ }^{\mathrm{a}, \mathrm{c}, \mathrm{e}}, \mathrm{S} . \mathrm{V}$. Rajesh ${ }^{\mathrm{f}}$, \\ P. Ajithprasad ${ }^{\mathrm{g}}$ \\ a CaSEs Research Group, Institució Milà i Fontanals, Spanish National Research Council, C/ Egipcíaques, 15, 08001, Barcelona, Spain \\ b Institut de Ciències de la Terra Jaume Almera, C/Lluis Solé Sabaris s/n, 08028, Barcelona, Spain \\ c CaSEs Research Group, Department of Humanities, Universitat Pompeu Fabra, C/ Ramon Trias Fargas, 25-27, Barcelona, 08005, Spain \\ ${ }^{\mathrm{d}}$ Climate Change and Security, Centre for Earth System Research and Sustainability, University of Hamburg, Grindelberg 7, 20144, Hamburg, Germany \\ ' ICREA-Institució Catalana de Recerca i Estudis Avançats, Spain \\ ${ }^{\mathrm{f}}$ Department of Archaeology, University of Kerala, Kariavattom Campus, Kariavattom, 695 581, Thiruvananthapuram, India \\ ${ }^{g}$ Department of Archaeology and Ancient History, The Maharaja Sayajirao University of Baroda, 390 002, Vadodara, India
}

\section{A R T I C L E I NFO}

Article history:

Received 28 March 2016

Received in revised form 13 November 2016

Accepted 13 November 2016

Available online xxx

Keywords:

Holocene

Drylands

Dunes

Settlement

Anthrosols

Soilscapes

\begin{abstract}
A B S T R A C T
This research aims at improving our understanding of open-air archaeological surface scatters in drylands, their extension and the intensity of human activities during their occupation. To do so, the study of physico-chemical proxies is integrated to that of archaeological artefacts by means of systematic field survey combined with laboratory sedimentary analyses and a robust statistical approach. In most dry regions, archaeological survey has traditionally aimed at the collection of artefacts. When present, the study of physical and geochemical samples has been limited to excavated archaeological levels. In this work, we evaluate the archaeological significance of physico-chemical proxies from surface samples collected within and around four mid and late-Holocene surface scatters in North Gujarat, a semi-arid region located at the south-west margin of the Thar Desert in India. The four archaeological scatters are found on top of fossilised sand dunes. Archaeologically, they represent subsistence strategies based on hunting and gathering, agro-pastoralism, or a succession/ mixture of the two. The four locations were systematically sampled across a linear transect. For each sampling unit, the archaeological materials were quantified and classified by means of a Linear Discriminant Analyses. Physio-chemical variables were ordinated in a PCA space and clustered through a Hierarchical Clustering. Results were displayed along the dune transect and integrated into a Correspondence Analysis. Significant differences are attested in the spatial distribution and content of $\mathrm{Ca}, \mathrm{P}$ and grain size, allowing us to suggest a set of distinct cultural soilscapes that characterise the dunes of the study area: vertisols (agric horizons in interdunal lower slopes), aridisols (relict dune surfaces in the mid-slope), and anthrosols (top dune). The last show a strong correspondence with the presence of archaeological artefacts, and the different intensity of human footprint are discussed accordingly to potential past subsistence strategies and the intensity of human occupation.
\end{abstract}

(C) 2016 Published by Elsevier Ltd.

\section{Introduction}

Surface scatters of archaeological materials are the most ubiquitous evidence of prehistoric human occupations with poor vegetation cover. These scatters, when recognised during field-walking, are often closely related to relict landscape features (e.g. dunes, water bodies and rock outcrops, see Tainter, 1979; Gallant, 1986; Wandsnider and Camilli, 1992; Fanning and Holdaway, 2001; Fanning et al., 2007; Blau et al., 2008; Bayón et al., 2012). Such relationships are not always easy to establish in drylands, as they are prone to severe erosion and deflation processes from multiple agents (aeolian, alluvial and anthropic) that rework surface sediments (Goudie, 2002). In

\footnotetext{
* Corresponding author.

Email addresses: fc.conesa@upf.edu (F.C. Conesa); Agustin.Lobo@ictja.csic.es (A. Lobo); j.alcaina.m@imf.csic.es (J. Alcaina); balbo@cantab.net (A. Balbo); marco.madella@icrea.cat (M. Madella); rajeshkeraliyan@yahoo.co.in (S.V. Rajesh); ajitkarolil@rediffmail.com (P.Ajithprasad)
}

such cases, two major factors limit our capability to identify surface scatters and interpret past occupations: 1) the difficult identification of relict surfaces (e.g. as a consequence of flattening erosive processes); and 2) archaeological palimpsests are made of mixed archaeological materials, especially in contexts characterised by little sediment accumulation (Read, 1986; Brantingham et al., 2007).

Archaeological survey has traditionally aimed at the collection of artefacts to create preliminary typo-chronological seriations. While useful, this approach lacks a shared set of criteria for the systematic classification of surface evidence in different parts of the world (Kantner, 2008; Bevan et al., 2013). Moreover, the classification of surface scatters is hampered by the heterogeneous preservation of different archaeological materials. For instance, lithic and pottery are often the most abundant evidence even though the original assemblages included organic materials and other more perishable remains (Fernández-López de Pablo and Barton, 2015; Jennings et al., 2015). To overcome such limitations, new approaches based on the identification of alternative proxies have been used to improve the signifi- 
cance of archaeological surveys in drylands (Burger et al., 2002; Allen et al., 2008; Beach et al., 2008; Deo et al., 2011; Markofsky et al., 2016). Information embedded in soils and sediments, for instance, highlight the importance of physico-chemical descriptors as a proxy of long-term human activity and occupation (Mallol and Bertran, 2010; Wilson, 2013; Sedov and Jacobs, 2012; Salisbury et al., 2013; Kluiving et al., 2013; French et al., 2014).

Here we present an explorative geoarchaeological approach aimed at refining survey methods for the classification of surface scatters in drylands. The aims were: 1) to understand the spatial relationship between surface archaeological artefacts and physico-chemical signatures (of geogenic or anthropic origin) in relict landforms (fossilised sand dunes and interdunes) and 2) to explore whether different past subsistence strategies (hunter-gatherer, agro-pastoral, mixed) generated different and detectable physico-chemical signatures. The approach was tested with mid-Holocene and late-Holocene surface scatters on fossilised sand dunes and interdunes in North Gujarat, a semi-arid region located at the SE margin of the Thar Desert (India).

\section{Background}

North Gujarat is a semi-arid ecotone between the Thar Desert to NW and the Sabarmati River to the SE. This is one of the driest ecoregions in India and it is highly sensitive to the shifts of the Indian Summer Monsoon (ISM). The local seasonal rivers West Banas, Saraswati, Rupen and Khari cross the three main physiographic units of the area (Fig. 1): 1) the Aravalli Hills, 2) the Quaternary alluvial plains and 3) the Little Rann of Katchchh, a broad saline and marshy intertidal estuary. Fossilised sand dunes are widespread in this land- scape. They are Late Pleistocene (ca. 100 to $14 \mathrm{kyr}$ ago) relicts of the maximum SW extension of the Thar Desert, which retired to its present dimensions between ca. $13 \mathrm{kyr}-5 \mathrm{kyr}$ following the Holocene configuration of monsoonal circulation and the fixation of aeolian sediments (Goudie et al., 1973; Raj et al., 2015).

In recent years, the alluvial plains of North Gujarat have been intensively surveyed, reporting more than 200 archaeological surface scatters, mostly found on the top of fossilised dunes (Bhan, 1994; Ajithprasad, 2004, 2011). However, only a few of these locations have been totally or partially excavated and contextualised with calibrated dates and with faunal and plant remains to help clarifying past subsistence practices. On the basis of these excavations it was possible to identify: 1) hunter-gatherers without pottery (ca. 8 to $5 \mathrm{kyr}$ BP) exploiting a wide range of food resources from seasonal marshlands; and 2) agro-pastoral groups with pottery whose subsistence strategies involved seminomadic pastoralism, the cultivation of fast-maturing crops and the gathering of wild plants (García-Granero et al., 2016). On the basis of the material culture, the agro-pastoral groups can be broadly divided into 2a) Anarta communities, that developed a regional Chalcolithic pottery tradition between 5 and $3 \mathrm{kyr}$ BP, and b) groups gravitating within the Indus Valley Civilisation (ca. 4 to 3 kyr BP, see Chase et al. 2014; Rajesh and Krishnan, 2014). This scenario contrasts with the heterogeneous descriptions from archaeological gazetteers reporting surface surveys. In general, there is a lack of consistency in the collection and description of surface archaeological materials. This situation is being aggravated by the accelerated spread of mechanised agricultural activities and irrigation infrastructures (Shah, 2014), all contributing to dune erosion and the masking and mixing of archaeological evidence.

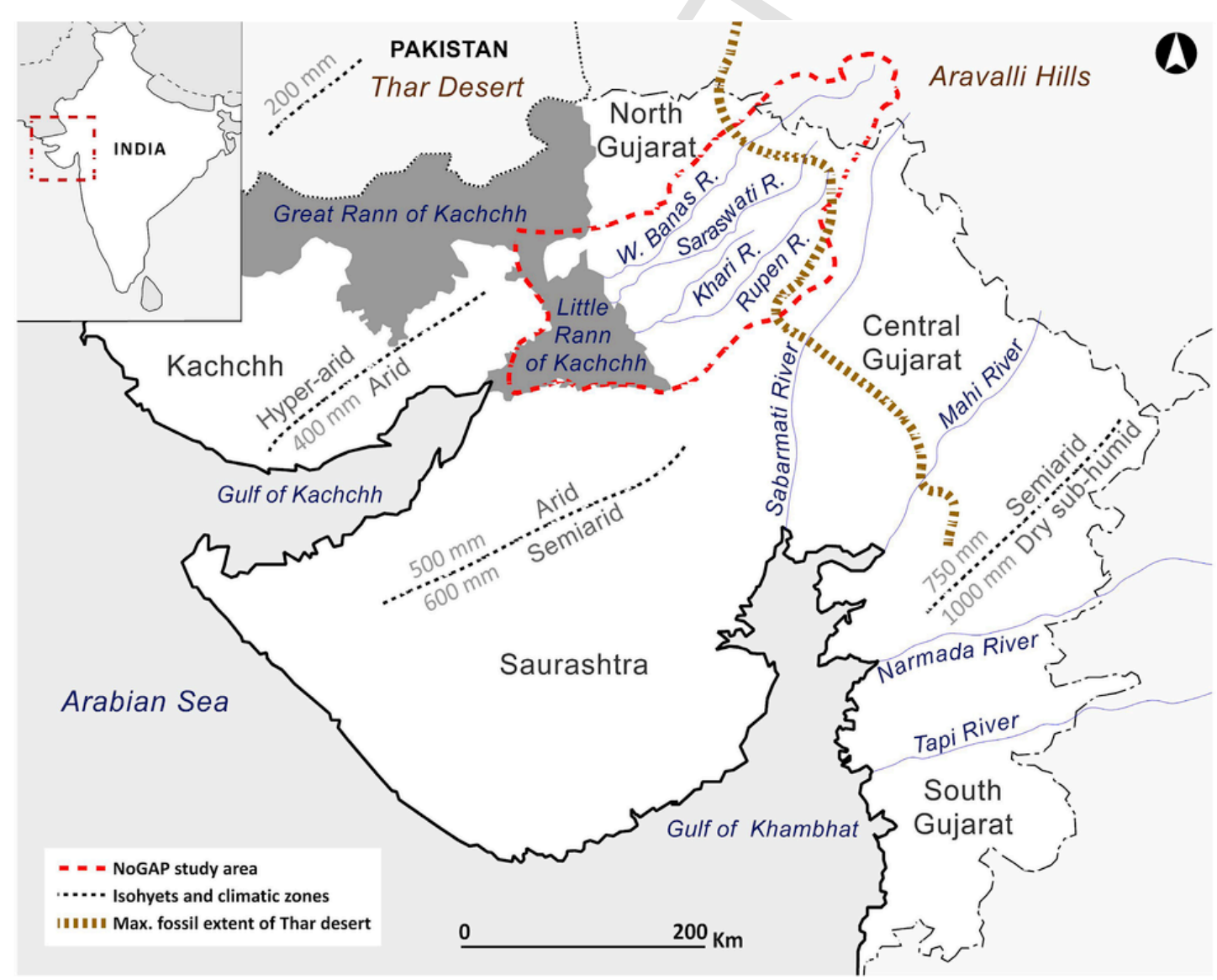

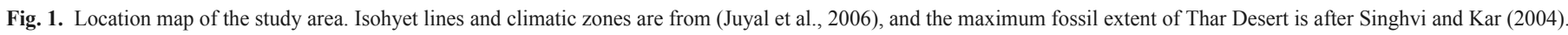




\section{Identification of depositional and post-depositional processes}

Previous remote sensing observations provided insights into the main North Gujarat physiographical traits, addressing the regional distribution and visibility of open-air scatters (Balbo et al., 2013; Conesa et al., 2015). The present work extends the regionally-based research by narrowing the focus to the local scale (dunes). By integrating archaeological data with physico-chemical proxies from surface sediments and soils we explore possible relationships between the distribution of surface assemblages and the geogenic and anthropogenic depositional and post-depositional processes.

\subsection{Distribution of surface assemblages}

This study first investigates the systematic quantification of surface archaeological assemblages and their spatial distribution on the dune surface. The starting hypothesis was that human activity led to concentrations of archaeological materials, and that these concentrations would be different (in types and frequency of materials) depending on the occupying groups (hunter-gatherers vs. agro-pastoralists). The presence and structure of archaeological scatters was assessed via a systematic transect survey.

\subsection{Identification of geogenic aeolian/alluvial sediments}

At geomorphological level, geogenic processes leading to dune fossilisation in this area have been described by Goudie et al. (1973). Following the last glacial-interglacial transition and the setting of the current ISM, accumulation processes progressively stopped in dunes at the periphery of the greater Thar Desert. Consistent seasonal precipitations and the alternation of cool-wet and dry-hot seasons contributed to dune fossilisation by: 1) depleting fine sediments from the dune tops to the lower interdunal areas (Wright, 1991, Singhvi et al., 2010), and 2) favouring the formation, by evapotranspiration, of cemented calcareous crusts (Goudie et al., 1973). Physico-chemical identification of these processes represents a necessary step to assess potential subsequent anthropogenic activities that might have changed the geogenic signature of relict dunes.

\subsection{Post-depositional anthropic processes}

This work specifically addresses the identification of anthropic markers from physico-chemical signatures in sediments and soils. Previous geoarchaeological research focused on identifying physical and geochemical signatures of human activities in situations where artefacts and ecofacts were not informative (see for example Goodman-Elgar, 2008; Zerboni et al., 2013).

At the same time, protracted human occupation can result in phosphorus (P) enrichment, with concentrations often higher by orders of magnitude. Archaeological research focused on soil $\mathrm{P}$ indicators in both off-site and on-site settings to distinguish areas of different intensity of anthropic activity and to define the extension of occupied areas (e.g. Sjöberg, 1976; Middleton and Price, 1996; Holliday and Gartner, 2007; Bevan and Wilson, 2013; Nielsen and Kristiansen, 2014). In semi-arid soils in particular, $P$ is fixed in soils from sources such as human and animal waste, stabling and grazing, and remains fixed through archaeological time scales (Holliday, 2004). Although $\mathrm{P}$ analysis is not indicative of specific activities, ethnoarchaeological work shows that high P presence is associated, among others, with cattle enclosures and food consumption events (Shahack-gross et al., 2003; Rondelli et al., 2014).

\section{Materials and methods}

\subsection{Study sites}

As a pilot experiment, we tested the suitability of integrating archaeological data with surface physico-chemical proxies in four selected dunes located within the Khari River basin. Based on previous archaeological work, these scatters represent the frequentation from groups with different subsistence strategies: hunting and gathering, agro-pastoralism, and a succession/mixture of the two.

\subsubsection{Hunter-gatherer scatter: Vaharvo}

Vaharvo is a dome dune situated near a seasonally inundated depression and surrounded by fertile alluvium plains (Fig. 2a). The site was first reported in the early 1980s (Bhan, 1994) and two $4 \times 4 \mathrm{~m}$ trenches were excavated by the NoGAP team in 2011 where large presence of microlithic artefacts and fragmented charred bones were observed. The trenches showed a uniform aceramic hunter-gatherer deposit of ca. $100 \mathrm{~cm}$, including the remains of three pits of different size and shape down to about $135 \mathrm{~cm}$. These levels were AMS dated to c. 5600-5000 cal BC (García-Granero et al., 2015).

\subsubsection{Agro-pastoral scatter: Gokhijadio}

The field of Gokhijadio was described as a dune surface with an agro-pastoral occupation due to the abundance of Anarta potsherds, as documented in the early 1990s (Ajithprasad, 2011), although it was never excavated (Fig. 2b). The dune elevation has been slightly eroded in recent times due to the intense cultivation of castor oil (Ricinus communis).

\subsubsection{Mixed scatters: Loteshwar and Kalrio}

Loteshwar is a prominent dune on the right bank of the Khari River that was first excavated in the early 1990s and then by the NoGAP team in 2009 (Fig. 2c). Loteshwar is one of the earliest Holocene hunter-gatherer occupations attested in north-western India (7168-4703 cal BC). The animal bones indicate the possible local domestication of Bos indicus (zebu) by Anarta groups (3861-2243 cal BC) prior to the establishment of urban Harappan communities in the region (Patel, 2009; Ajithprasad and Sonawane, 2011). The excavations highlighted a relatively long hunter-gatherer occupation of the dune, contemporaneous to that of Vaharvo. Above these deposits, there is an agro-pastoral Anarta occupation (2700-2300 cal BC) with pits (Balbo et al., 2015; García-Granero et al., 2016).

Kalrio dune lies $600 \mathrm{~m}$ southwest of Loteshwar at the confluence of the Khari and Orumana rivers (Fig. 2d). The surrounding interdune fields are mostly filled with alluvial deposits from recurrent monsoonal flooding. The dune was reported as an aceramic microlithic site in the early 1990s (Bhan, 1994) but it has never been excavated. However, previous surface surveys documented the presence of small sherds, lithic and bones, thus suggesting a succession of different occupations similarly to those reported in Loteshwar (Madella et al., 2012).

\subsection{Dune transects and sampling strategy}

A linear transect was set up in each of the four sites. Each transect was centred on the highest point of the dune and the orientation was chosen to include the majority of surface scatters identified by previous observations. Sampling spots of one square meter were placed along the sampling transect at regular intervals: every $5 \mathrm{~m}$ for the first $50 \mathrm{~m}$ from the dune top and every $10 \mathrm{~m}$ for the rest of the transect, 

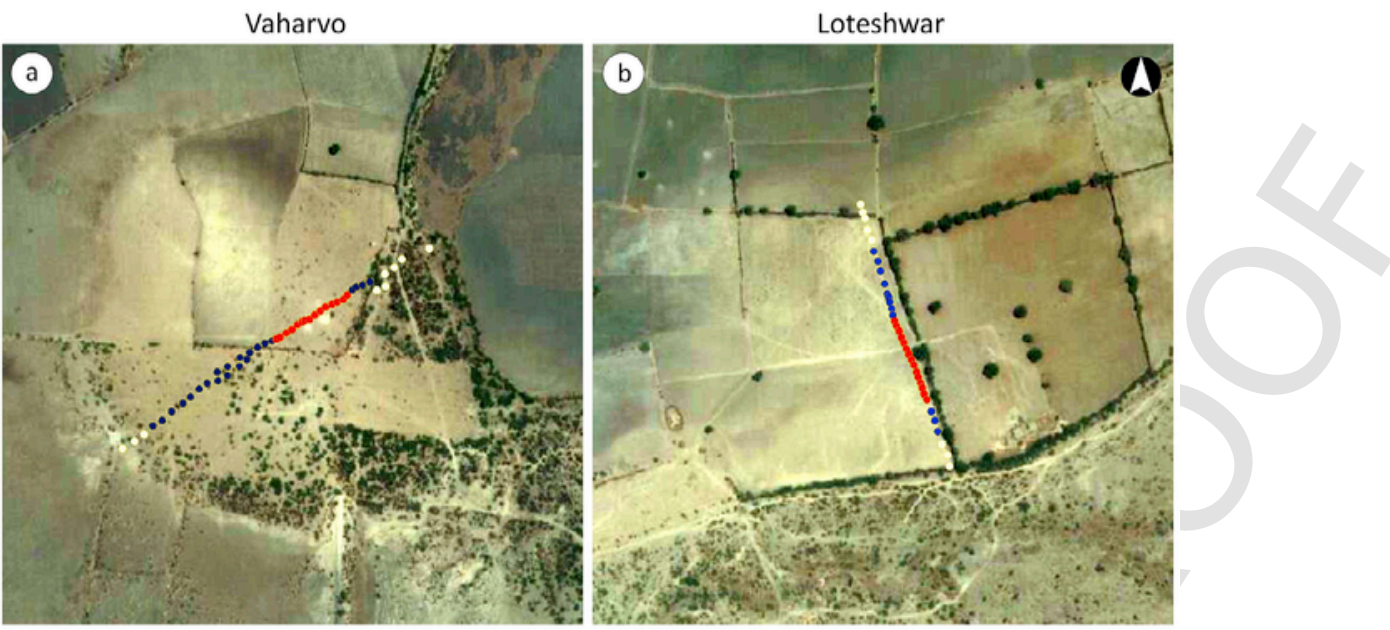

Kalrio
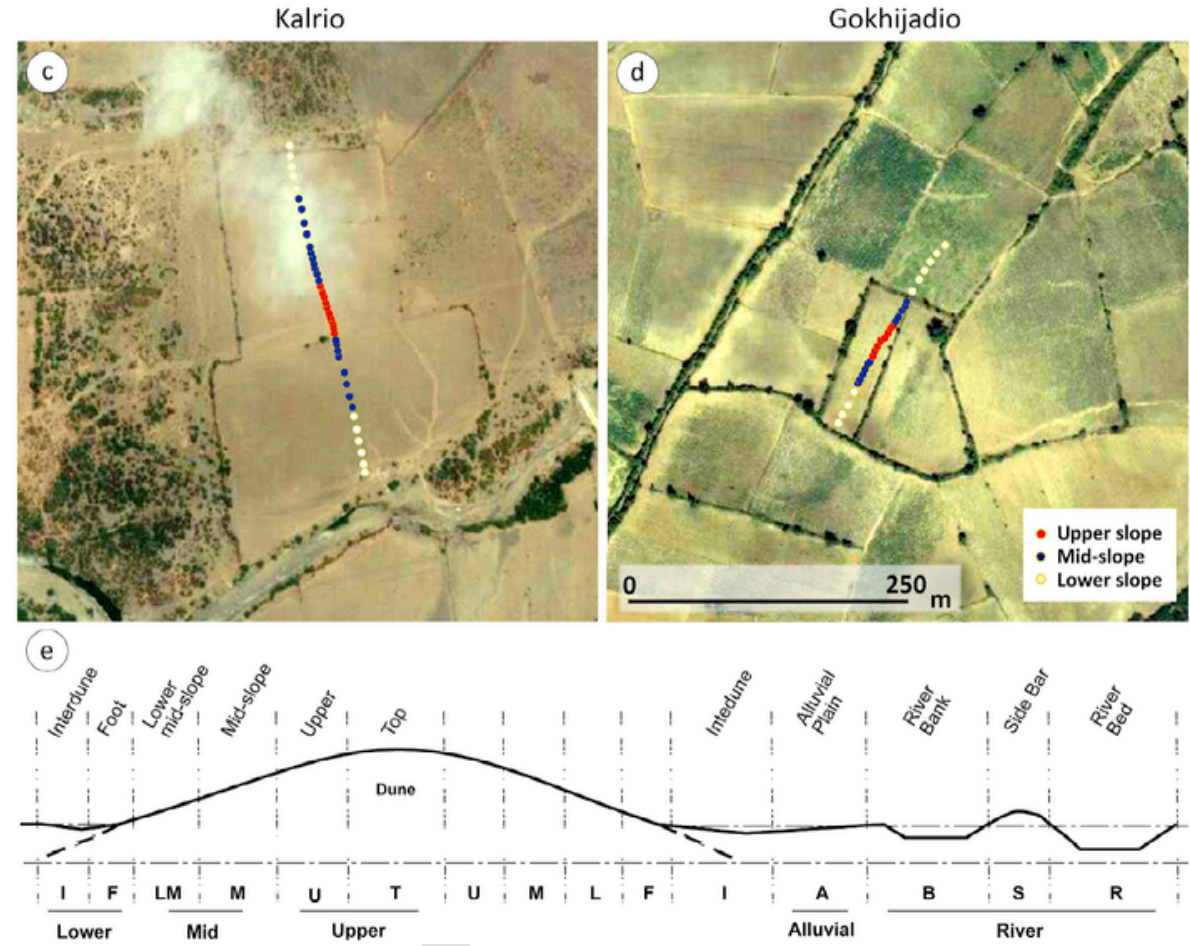

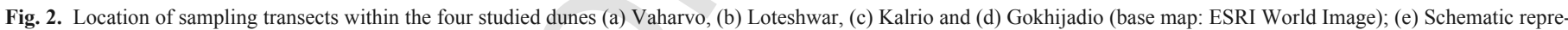
sentation of a dune slope with catena units used for the archaeological and physico-chemical characterisation of fossilised sand dunes.

until reaching the nearest maximum depression (i.e. interdune or water body). This approach was chosen to optimise fieldwork time while accounting for areas with the highest concentrations of archaeological materials. For each sampling square, surface material was systematically collected, and then described, counted and weighed in the laboratory. A surface sediment sample of the first $5 \mathrm{~cm}$ layer was collected from the centre of each sampling square (physico-chemical analyses). We also recorded in situ semi-qualitative surface sediment observations (i.e. Munsell colour, texture and grain size) and land cover/land use type.

Our dataset consists of 151 samples from the sampling transects of Vaharvo (46 samples), Gokhijadio (29 samples), Loteshwar (35 samples) and Kalrio (41 samples). The geographical position of each sampling unit was described by a categorical variable following a classified scheme of the surface catena, representing the succession of slope units within a dune profile (Fig. 2e).

\subsection{Physico-chemical analyses}

Particle size distribution (PSD) of fine earth sediments $(<2 \mathrm{~mm})$ was carried out in order to identify potential geogenic and anthropic patterns of sediment transportation, deposition and re-working. PSD was estimated using a CoulterLS ${ }^{\complement}$ laser-particle-analyser. Samples of ca. $0.5 \mathrm{~g}$ were taken and suspended in $10 \%$ sodium polyphosphate deflocculant solution (Puy and Balbo, 2013). Samples with high organic content where pre-treated with hydrogen peroxide to remove organic material (Goldberg and Macphail, 2006). Values in microns $(\mu \mathrm{m})$ were converted into phi units following established standards (Krumbein, 1938; Puy et al., 2014). Loss-On-Ignition (LOI) was used to analyse the content of soil moisture, soil organic matter, charcoal, calcium carbonate and mineral residue, used as proxies for differentiate alluvial soils from aeolian soils. LOI measures followed $4 \mathrm{~h}$ cy- 
cles of drying at $105^{\circ} \mathrm{C}$, and combustion at $400{ }^{\circ} \mathrm{C}, 550{ }^{\circ} \mathrm{C}$ and $925^{\circ} \mathrm{C}$ (Heiri et al., 2001). Geochemical multi-element signatures were measured by Inductively Coupled Plasma Atomic Emission Spectroscopy (ICP-AES) in order to characterise inorganic chemical indicators of dune stabilisation, anthropic occupation and land use practices (35 major elements; Wilson et al., 2008). Samples were pre-treated with aqua-regia and analysed at the ALS Laboratory Group in Seville (Spain).

\subsection{Statistical analyses}

The main steps of our methodology were as follows (Fig. 3):

1. Diagnose sample units in terms of human occupation based on the quantification of archaeological descriptors, for which we inspected and diagnosed a sub-sample ("training set") to fit a Linear Discriminant Analyses (LDA) model that was subsequently applied to extend the diagnostic to the rest of samples. This LDA also served to evaluate the consistency of the archaeological assemblages with our data.

2. Explore the spatial distribution of the physico-chemical variables, which we did through the distribution of physico-chemical clusters resulting from a hierarchical clustering of samples described by their physico-chemical variables in a principal component reduced space.

3. Investigate the associations between physico-chemical variables and archaeological variables, which we did through a Correspondence Analysis (CoA) of the contingency table of archaeological classes vs. physico-chemical clusters, which highlights their relationships in a reduced space.

All the analyses were performed in R software environment (RStudio version 0.98.1049, R-Core-Team, 2014). Original raw data is supplied as Supplementary Electronic Material.

\subsubsection{Data cleaning and transformation}

Data cleaning and transformation was applied after performing an explorative Shapiro-Wilk test to check for normality in the physico- chemical data. In preparation for statistical analyses, non-normally distributed data were transformed: 1) an additive log-ratio was applied to LOI and PSD data for removing closure effects (i.e. between variables that sum a constant); to increase normality, 2) a $\log 10$ transformation was applied to ICP-AES data; and 3$)$ a $\log (+1)$ transformation was applied to archaeological weights. All data were then transformed to Z-scores values (see Shennan, 2004).

A total of 35 variables were considered, comprising one group of categorical variables (slope units) and three groups of continuous variables (archaeological weight, physical analyses and geochemistry). Qualitative archaeological and in situ sediment characterizations were excluded from the statistical analyses, and were used only to cross-validate the laboratory and statistical results with field observations.

\subsubsection{Classification of sampling units according to archaeological} data

We established four simplified major classes of archaeological surface assemblages according to the weight and frequency of pottery, lithic, and bones:

- Class 1 - Aceramic microlithic evidence (AM): characterised by mid to high density of lithics, variable amount of fauna and very low or inexistent ceramic assemblages.

- Class 2 - Predominance of potsherds evidence (PP): represented by a high density of pottery and clay artefacts, with variable amounts of fauna and mid to low evidence of lithics.

- Class 3 - Mixed evidence: characterised by mid to high densities of all types of evidence.

- Class 4 - Low evidence: samples with lack of or very low archaeological evidence.

Each class refers to a neutral indicator that indicates different frequencies in the archaeological assemblage, thus avoiding any overtone produced by chronological, cultural, and socio-economic definitions. Other recovered materials, such as palette stones, grinding stones and clay lumps were excluded from our classification as they

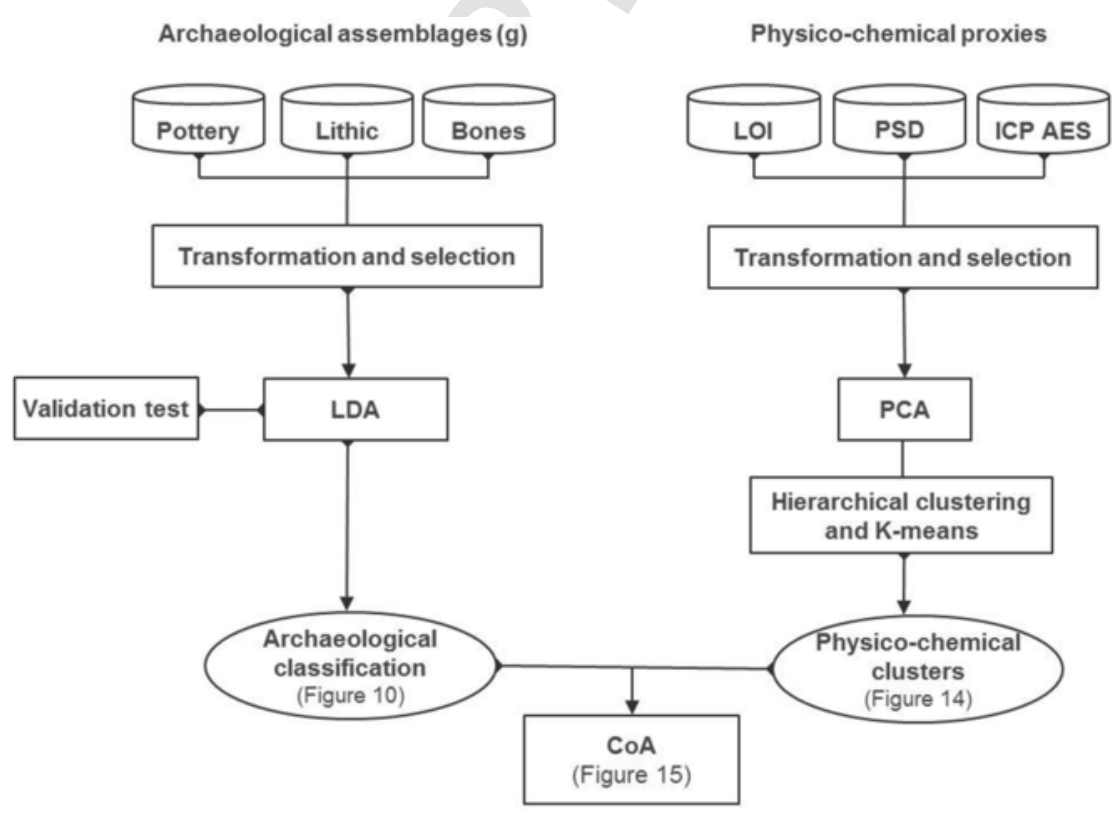

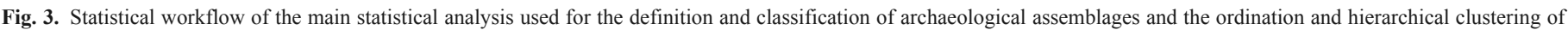
physico-chemical variables. 
were detected in less than $20 \%$ of the samples. However, they were used to cross-validate the statistical results.

In order to formally assign the 151 dune samples to a class according to our scheme, we applied LDA as a supervised machine learning method. Supervised machine learning methods use a relatively small subsample that has been labelled by the user (the "training set") to derive a model that is evaluated on another labelled subsample (the "validation set"), and then applied to all samples. LDA is akin to PCA in the sense that is an ordination in a reduced space, but maximizes the among-group variance as specified in the training set, instead of the total variance. LDA produces a linear transformation in which the classes are optimally separated, and results on a set of vectors recording the probability of a given sample to belong to each class. Boundaries between classes are linear. In terms of classification, LDA results are close to those produced by multiple logit regression (James et al., 2013). An important advantage of LDA is that is produces both an ordination and a classification. Furthermore, the LDA ordination integrates both the structure of the data (as PCA does) but also the knowledge input by the user in terms of diagnostics in the training sets. The ordination of the classes in the LDA spaces let the user check the consistency of the diagnostics and the data.

In our case, we randomly selected and diagnosed 32 samples ( 8 samples for each type of archaeological evidence: AM, PP, mixed and low) based on the weight of archaeological evidence, regardless of the dune of origin. We then run a LDA using a "training set" of 20 samples ( 5 samples from each class), which was validated with the remaining 12 samples ("evaluation set", 3 samples from each class). After validation, the model was applied to all samples, i.e., each sample was assigned to the archaeological class for which LDA calculated the highest probability. A Wilks-Lambda p-value test confirmed the significance of the partition of the multi-variate space in terms of the archaeological classes. Results were plotted with the samples labelled by their respective classification on the LDA ordination space and at their positions on the dunes.

\subsubsection{Ordination and hierarchical clustering of sampling units according to physico-chemical variables}

In order to investigate the spatial distribution of physico-chemical variables, we produced an abridged representation of the multi-variate dataset (151 samples x 21 variables) by grouping similar samples into unsupervised physico-chemical clusters, and then plotted the samples labelled by their respective clusters both on the ordination space of a Principal Component Analysis (PCA), and at their positions on the dunes.

Clustering was performed on the data matrix of Principal Components (PCs) rather than on one of the 21 physico-chemical variables, considering that Euclidean distance provides a weak dissimilarity measure in the presence of high among-variables correlation. Thus, a PC transform was calculated on the dataset of physico-chemical variables and the resulting data matrix of 151 samples x 21 PCs was submitted to a hierarchical clustering using Euclidean distance as similarity measure, and Ward's aggregation method to ensure low variance clusters (Calegari et al., 2013; Dirix et al., 2013a, 2013b). The resulting dendrogram was cut using a dissimilarity threshold defined by the stopping threshold rule proposed by Mojena (1977), which selects the "best" number of clusters based on the distribution of a clustering criterion associated with each hierarchical level. Following Milligan and Cooper (1985) we scaled the standard deviation values by a factor of 1.25 to improve the performance of the stopping rule. Hierarchical clustering, being a bottom-up process in which centroids are progressively updated, produces reliable final centroids but does not guarantee that all samples be actually assigned to its most similar final centroid, thus we run a k-means classification initialized by the centroids of the hierarchical clustering to refine this result.

\subsubsection{Correspondence Analysis}

We investigated the relationships between archaeological classes and physico-chemical clusters through Correspondence Analysis $(\mathrm{CoA}) . \mathrm{CoA}$ orders in a reduced space the relationships between two categorical variables recorded in a contingency matrix, in such a way that categories that have a high coincidence have a short Chi-square distance and are placed close together in the CoA space (Greenacre, 2007). The plot of the data in the space defined by the first 2 or 3 axes allows for a fast assessment of the relationship between the categories of the two variables and the strength of the relationship is evaluated by a Chi-square metric. In our case, we applied CoA to the contingency matrix defined by tabulating the cross-frequencies of archaeological classes and physico-chemical clusters in terms of number of samples (i.e. count $C(i, j)$ in the contingency matrix would be the number of samples that were assigned to both archaeological class $i$ and physico-chemical cluster $j$ ).

\section{Results}

A graphical overview of the distribution of the main archaeological and physico-chemical variables along each catena is provided in Fig. 4 (Vaharvo), Fig. 5 (Loteshwar), Fig. 6 (Kalrio) and Fig. 7 (Gokhijadio).

\subsection{Archaeological variables}

\subsubsection{Distribution of archaeological evidence}

Archaeological remains are generally well clustered in the upper part of the dunes (top and upper slopes) and decrease towards the lower portions of the dune profile (foot dune and interdune areas, see also Table 1).

At Vaharvo, the archaeological surface assemblage is mostly represented by bone fragments ( $87 \%)$ and lithics (10\%). Although highly fragmented, microliths are uniformly dispersed along the upper slope and are more abundant in Vaharvo than in the other three scatters. Some grinding stones were collected in the mid and upper portions of the dune. Occasional Early Harappan sherds (ca. 4 kyr BP) and few unidentified protohistoric pottery sherd suggest sporadic later occupations. The visibility of surface assemblages is lower in the southwest upper and mid-slope, which corresponds to currently highly disturbed areas (i.e. field margin path).

At Loteshwar, archaeological materials decrease at the very top of the dune and are more abundant down the slope, in the vicinity of the dune summit. Faunal remains (59\%) and sherds (35\%) are well spread along the upper and mid portion of the dune, while most of the lithic assemblage $(3.7 \%)$ is concentrated at the very top of the dune. Less-abundant materials such as grinding stones, clay lumps (associated to the Anarta groups and the Indus Valley Civilisation) and palette stones are present along the upper and mid portions of the dune.

At Kalrio, the surface assemblage shows all typologies well-distributed along the upper and mid dune profile. Bone fragments are the most abundant material (53\%) with fewer sherds (21\%) and significantly more microliths $(17 \%)$ than the nearby site of Loteshwar. Palette stones and clay lumps are also present, as well as a high number of grinding stones $(6 \%)$.

Finally, Gokhijadio shows several differences compared to all other sites, with an assemblage mainly composed by large fragments of Anarta sherds (84\%) and small fragments of charred bones (7\%). 


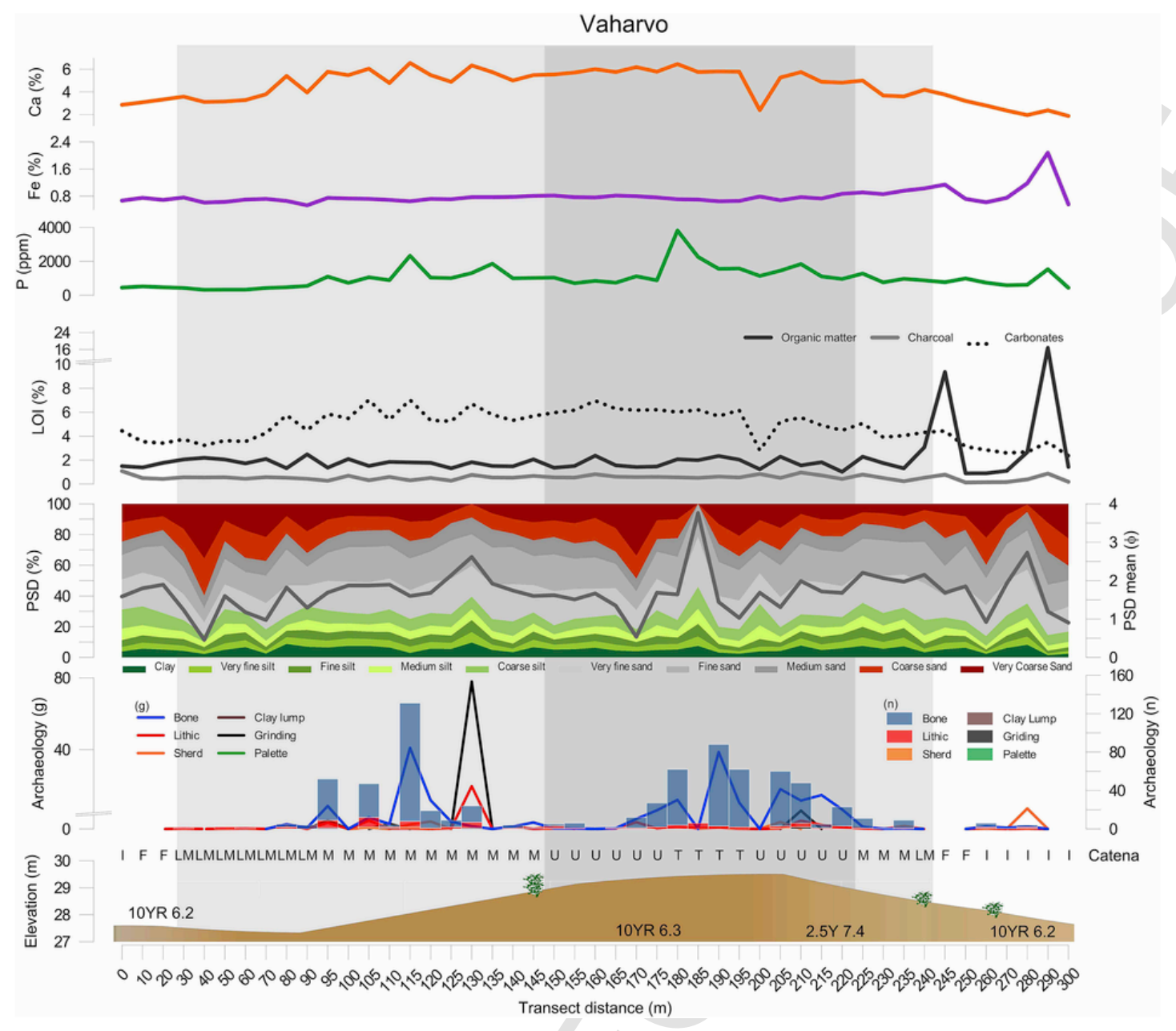

Fig. 4. Distribution of archaeological and physico-chemical proxies along the sampling transect of Vaharvo.

Lithics, palette stones and grinding stones were not recovered, but there is a noteworthy presence of clay lumps.

\subsubsection{Classification of sampling units according to archaeological data}

The LDA aligned each archaeological sample unit with the type of archaeological assemblage by means of the significance (total weight) of archaeological surface remains. A Wilks-Lambda of 0.0379 (p-value $<2.2 \mathrm{e}-16$ ) rejected the null-hypothesis, thus suggesting robust differences in terms of archaeological variables among the predefined types of archaeological classes (AM, PP, mixed sites and low evidence). Our supervised classification agrees well with the archaeological classification: the evaluation dataset showed an accuracy of $91 \%$ (proportion of samples in which predicted classes were coincident with observed diagnostics). The plot of the archaeological samples in the canonical plane of the first two LD components (Fig. 8a and b) ordinates, as expected, the two most different classes (AM and $\mathrm{PP})$ at the extremes, with the mixed class and low evidence class at the upper and lower intermediate positions. Fig. 9 shows the spatial distribution of the archaeological classification on the dunes after applying the LDA model over the full archaeological dataset. Samples with low evidence (class 4) are mostly distributed along the lower portion of the dune profile in all transects, with some on the mid slopes of Loteshwar, Kalrio and Gokhijadio. A disparity is observed at the mid and upper portions of Vaharvo dune, where most of the samples are classified as low evidence with some aceramic microlithic evidence (class 1). The upper portion of Loteshwar is mostly characterised by mixed evidence (class 3 ), although potsherds have high frequency at the top of the dune and in some samples at the mid slope. The archaeological assemblages of Kalrio are mostly distributed along the upper dune, and represent small clusters of aceramic microlithic and mixed assemblages. Far more different is the classification of Gokhijadio upper and mid dune slope samples, presenting a uniform cluster of potsherds, which corresponds well with the archaeological quantification described in the previous section.

\subsection{Physico-chemical variables}

\subsubsection{Particle size distribution}

Overall, very-fine and fine sand fractions are found in the interdune and in the lower slopes (between 3 and 2 mean $\varphi$, see Table 2). A general increase towards the medium sand fraction is observed in the mid-slope (2-2.36 mean $\varphi$ ), whereas the top and upper slopes of Vaharvo and Kalrio are characterised by medium to coarse sand fractions (1.37-1.90 mean $\varphi$ ). This trend is not observed at Loteshwar and Gokhijadio, where fine sand grains increase in the upper portions of the dune, with values similar or higher than those found at the interdune edges (between 2.10 and 3.50 mean $\varphi$ ). 


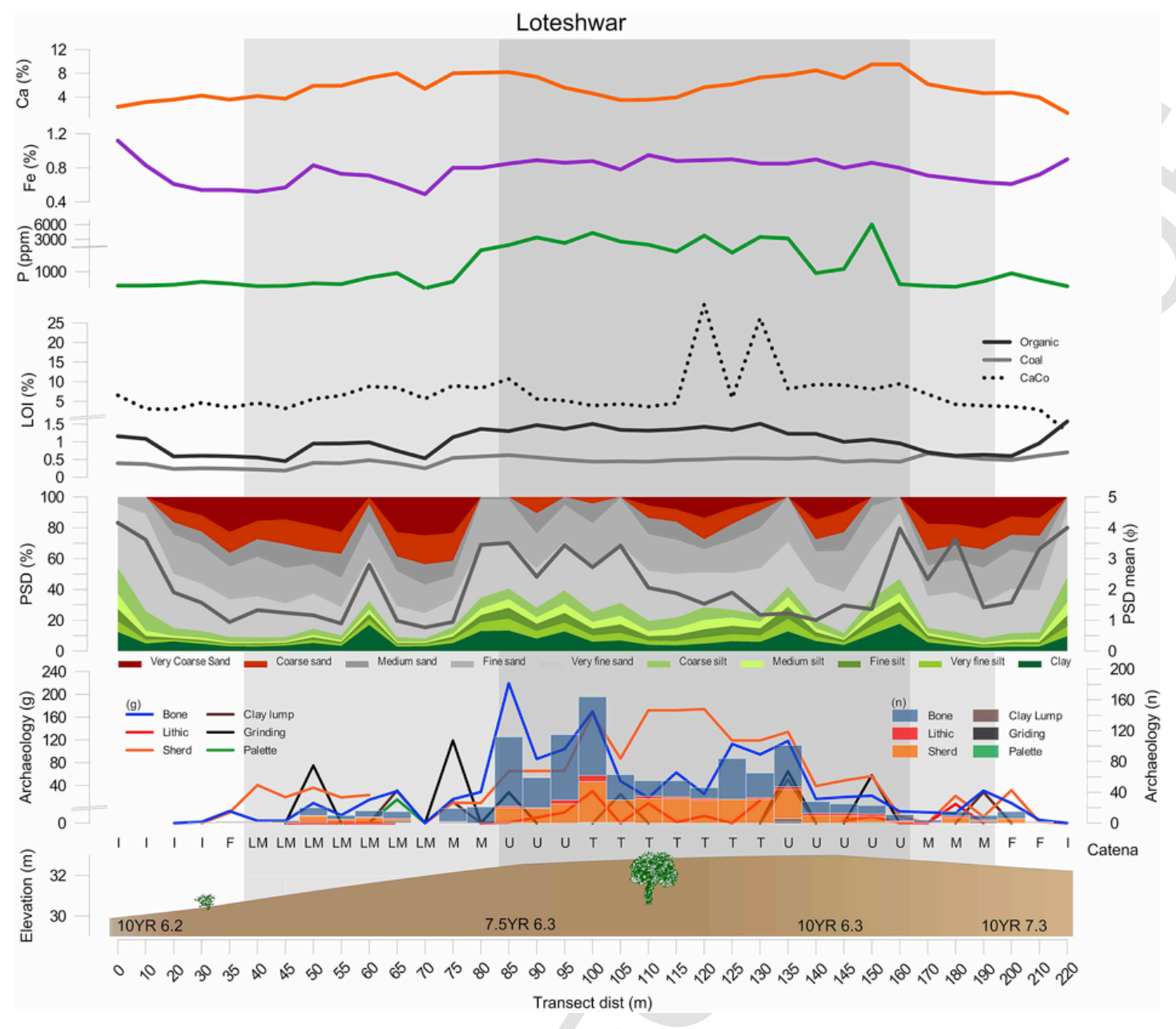

Fig. 5. Distribution of archaeological and physico-chemical proxies along the sampling transect of Loteshwar.

\subsubsection{Loss on ignition}

Proxies for content of organic matter, charcoal and calcium carbonates show clear differences between the lower interdune area and the dune slopes (Table 2). A general increase of carbonates is observed along the dune slope with highest values at the top of the dune (reaching a mean of $11 \%$ in Loteshwar). Some outliers of carbonates concentrations are identified in Kalrio, Gokhijadio and Loteshwar. Charcoal content also follows a somewhat increasing pattern towards the dune top, with the higher values recorded at Kalrio dune top (mean $0.70 \%$ ). Highest contents in organic matter are mostly found in Vaharvo, and they increase downslope towards the interdunal areas (mean 4\%). Organic matter is also slightly higher in interdune samples outside the main transects, and it decrease in mid-slope samples. Relative high organic matter content (mean $>1.20 \%$ ) is found at the upper catena of Loteshwar and Kalrio, possibly related to plant remains from nearby trees and corresponding modern resting areas used by local herders.

\subsubsection{Multi-element geochemistry data}

A correlation matrix for all ICP-AES elements is shown in Fig. 10. $\mathrm{Ca}$ is strongly correlated with alkaline earth metals such as $\mathrm{Sr}$ and $\mathrm{Ba}$. $\mathrm{Ca}$ increase towards the top of the dune in all dunes (Table 2). Vaharvo, Loteshwar and Kalrio top samples have an average of $5 \%-7 \%$ of $\mathrm{Ca}$, whereas interdunal samples have lower $\mathrm{Ca}$ content $(2-3 \%)$. The same pattern occurs in Gokhijadio, although the overall
Ca content is lower $(0.20 \%$ at the interdune and $3.25 \%$ at the top). At Loteshwar and in some Kalrio samples, the high $\mathrm{Ca}$ in the upper portion of the dune is not constant and slightly diminishes at the dune summit.

Transition and post-transition metals ( $\mathrm{Al}, \mathrm{Cr}, \mathrm{Ni}, \mathrm{Zn})$ are also highly correlated, as well as silicate related elements $(\mathrm{Fe}, \mathrm{Al}, \mathrm{K})$. Metallic and silicate related elements (e.g. Fe) are mostly concentrated in samples close to interdunal depressions $(0.80-0.90 \%)$ with a decreasing general pattern towards the upper slopes. Exceptions are the top samples from Loteshwar and Gokhijadio, having higher $\mathrm{Fe}$ and metallic concentrations strongly related with the presence of finer grain size sediment (see 5.2.1.)

In contrast to the general correlation patterns, $\mathrm{P}$ is the only element showing negative dependence with other elements. All the upper slope samples have high content of $\mathrm{P}$, reaching in a few cases values of $>5000 \mathrm{ppm}$, whereas interdunal concentrations are low (in the order of 300-500 ppm). The increasing pattern of $\mathrm{P}$ occurs from mid-slope samples in all dunes.

\subsubsection{Ordination and hierarchical clustering of physico-chemical variables}

The dendrogram resulting from the hierarchical clustering based on physico-chemical variables is shown in Fig. 11a. The resulting 9 clusters, and the ordination of physico-chemical variables, are represented on the plane of the first two axes of the PCA (Fig. 11b). Boxplots for each cluster are provided in Fig. 12. Clusters are also repre- 


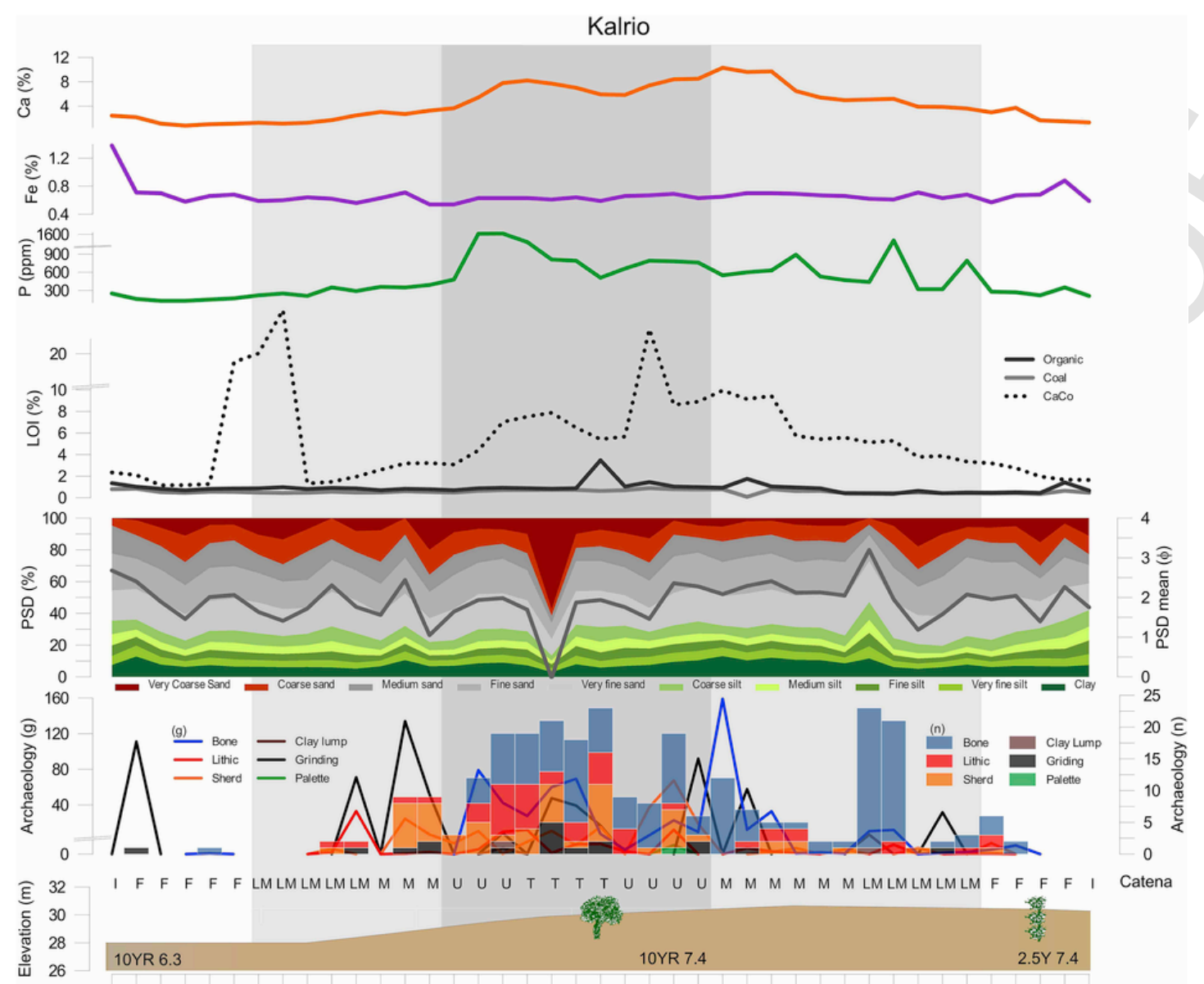

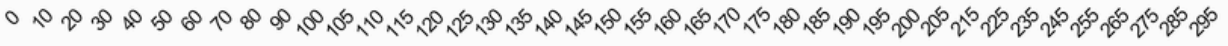
Transect dist (m)

Fig. 6. Distribution of archaeological and physico-chemical proxies along the sampling transect of Kalrio.

sented along the dune axes in Fig. 13 to better understand their spatial distribution. According to the analysis illustrated in Figs. 11-13, we propose the following cluster descriptions:

- Cluster 1 (37 samples) groups most of the samples from Vaharvo. It is characterised by a slightly high content of fine grain particles and organic debris. $\mathrm{P}$ concentrations are highly variable and $\mathrm{Ca}$ concentration is relatively high.

- Cluster 2 (24 samples) groups most of the Kalrio top dune samples, the mid-slope to foot samples of Loteshwar, and a few samples from the lower portion of Vaharvo. This cluster is mostly characterised by a very high concentration of $\mathrm{Ca}$ and carbonates. The sediment is sandy with low content of fine grain size. Fe and metallic elements have slightly lower concentrations than Cluster 1, whereas P concentration is higher but still variable.

- Cluster 3 (25 samples) groups lower mid-slope and foot samples from Loteshwar and Kalrio, with some from the foot of Vaharvo. This cluster groups samples with higher concentration of $\mathrm{Ca}$ and carbonates, sandy sediments and a low concentration of $\mathrm{P}$.

- Cluster 4 (5 samples) and Cluster 7 (16 samples) group foot and interdune samples from Vaharvo and Kalrio, but also lower mid-slope samples from Gokhijadio. High values of silty sediment, organic matter and charcoal are prevalent in cluster 4, whereas cluster 7 has less charcoal content. Both clusters show low concen- trations of $\mathrm{Ca}$ and $\mathrm{P}$, whereas metallic and silicate elements increase.

- Cluster 5 (20 samples) groups mid and upper samples from Gokhijadio and a few from the lower slopes of the other transects. This cluster is characterised by very low $\mathrm{Ca}$ content and high variability of $\mathrm{P}$ (but not as much as cluster 6), whereas $\mathrm{Fe}, \mathrm{K}, \mathrm{Mg}$ and fine grain particles are all higher than in the previous clusters.

- Cluster 6 (18 samples) groups samples from the upper slope of Loteshwar, and it is heavily associated with the high concentration of $\mathrm{P}$ and a slightly elevated concentration of $\mathrm{Ca}$ together with a predominance of fine grain particles.

- Cluster 8 (1 sample) is an outlier characterised by high carbonates in the lower slope of Kalrio.

- Cluster 9 (5 samples) groups the northeast interdune samples of Gokhijadio, showing a very low concentration of $\mathrm{Ca}$ and carbonates together with well-defined organic matter in silty sediments.

\subsection{Correspondence analysis (CoA)}

The results of the two classifications were integrated into a contingency table (Table 3) and a CoA was applied to better understand the relationships between archaeological assemblages and physico-chemical clusters. A chi-square test of the contingency table ( $p$-value $1.544 \mathrm{e}-13$ ) confirmed the robustness of association between different classifications. Fig. 14 shows the relative positions of each classifica- 


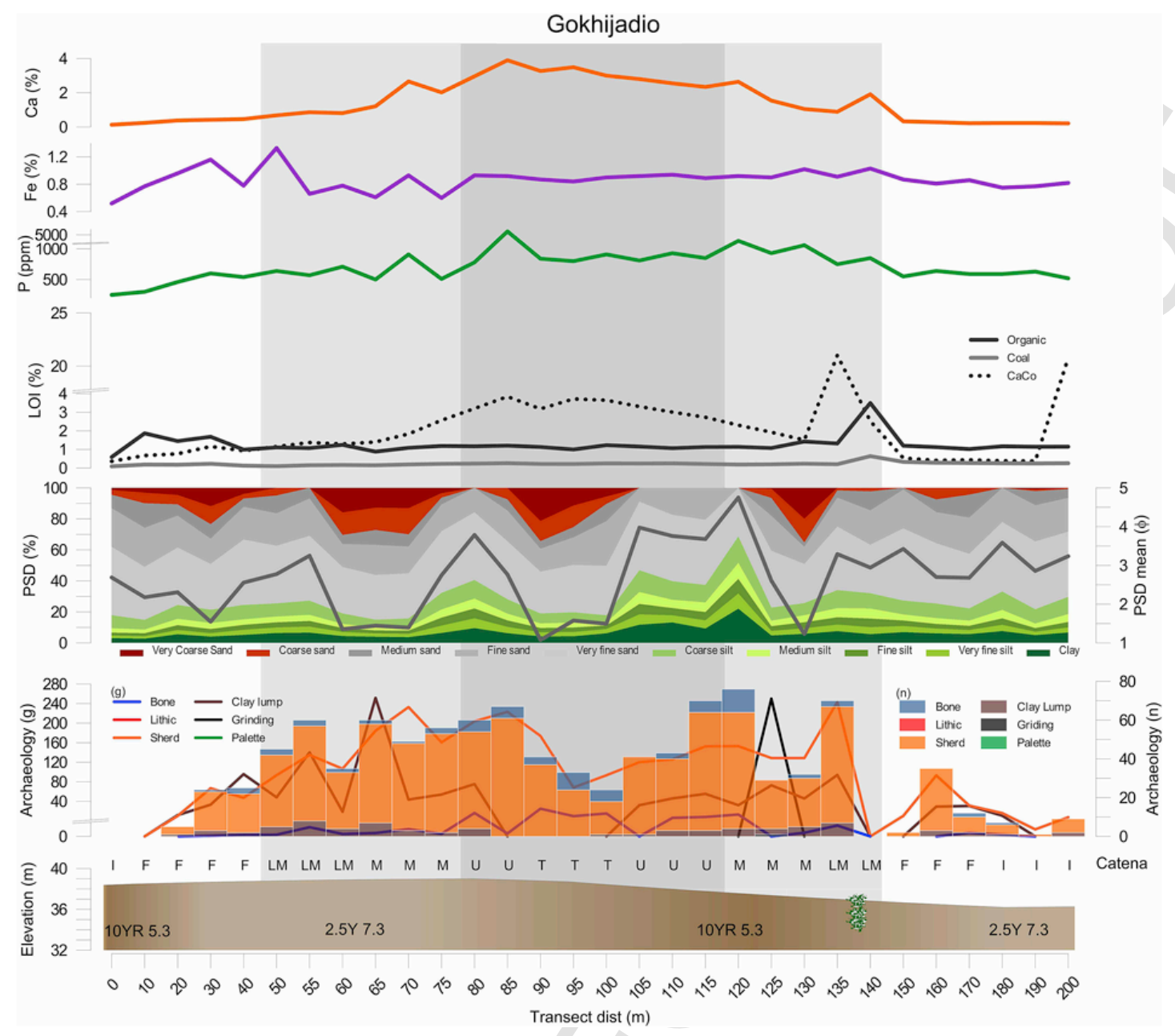

Fig. 7. Distribution of archaeological and physico-chemical proxies along the sampling transect of Gokhijadio.

tion in the plane defined by the first 2 axes of the CoA (accounting for, respectively, $55.6 \%$ and $34.7 \%$ of total inertia).

CoA highlights a strong correspondence between specific physico-chemical clusters and types of assemblages. Aceramic microlithics are closely associated to cluster 2 while potsherds assemblages are associated to cluster 5 . Mixed assemblages are associated to cluster 6 , and those samples with low or virtual absence of archaeological evidences are associated to either cluster 3 and/or 4 . Low evidence assemblages have also close correspondence to cluster 1 .

\section{Discussion}

\subsection{Archaeological classification}

In the LDA ordination (Fig. 8), a group of samples classified as low evidence assemblage show a denser cluster that corresponds to those samples with the lowest abundances, whereas the rest are more scattered depending on whether the abundances tend to approach them to either AM or PP assemblages. This distribution might indicate two different origins for these samples: 1) those without human occupation and 2) those with low presence of materials because of low-impact occupation. Samples with absence of archaeological materials mostly correspond to interdune and lower slope samples. Low presence of materials is attested mostly on the top dune of Vaharvo. This low archaeological impact corresponds well with the excavation of the dune deposit, which reported an aceramic hunter-gatherer oc- cupation dated to the second half of the sixth millennium cal. BC, disturbed only by an isolated Early Harappan burial with associated pottery (Madella et al., 2012; Mushrif-Tripathy et al., 2014).

The samples from the mixed class (class 3 in section 4.4.2.) are distributed between the spaces of aceramic microlithic (class 1 in section 4.4.2.) and predominance of potsherds (class 2 in section 4.4.2.) classes in the LDA plane. Their distribution along the top dune of Lotheswar is in agreement with the two levels of occupation (aceramic hunter-gatherer and agro-pastoral) uncovered from the dune deposit (García-Granero et al., 2016).

The transects in dunes without excavated deposits show two different patterns. The absence of lithic artefacts and abundance of potsherds and clay lumps in Gokhijadio (class 2) suggests a pastoral/ Anarta occupation. In contrast, the evidence of aceramic microlithics assemblages (class 1) in Kalrio may reflect a similar occupation of that found in Vaharvo, although the occurrence of potsherds could indicate posterior occupations from pastoral groups (as show in evidence from class 3). However, the attribution of surface lithic assemblages to either hunter-gatherer (Mesolithic) or pastoral groups (Calcolhitic) is controversial. Little variation in lithic production over millennia has hampered a straightforward typo-chronological characterisation (Gadekar et al., 2014). Moreover, Patel (2009) argued that due to the long time span and varied nature of lithic deposits in the area, the term "microlithic" should be used only as a neutral descriptor referring solely to the stone tool industry. Interestingly, the ordination of the aceramic microlithic samples in the LDA plane seems to 
Table 1

Archaeological quantification (n) for each sampling transect along major dune catena units.

\begin{tabular}{|c|c|c|c|c|}
\hline & Vaharvo. & Loteshwar & Kalrio & Gohkijadio \\
\hline \multicolumn{5}{|l|}{ Fauna } \\
\hline Upper & 370 & 589 & 74 & 40 \\
\hline Mid & 275 & 88 & 66 & 31 \\
\hline Lower & 7 & 12 & 6 & 7 \\
\hline$\%$ & 87.87 & 59.35 & 53.68 & 7.72 \\
\hline \multicolumn{5}{|l|}{ Lithics } \\
\hline Upper & 32 & 38 & 33 & 0 \\
\hline Mid & 41 & 5 & 12 & 0 \\
\hline Lower & 2 & 0 & 2 & 0 \\
\hline$\%$ & 10.11 & 3.70 & 17.28 & 0 \\
\hline \multicolumn{5}{|l|}{ Sherds } \\
\hline Upper & 2 & 369 & 37 & 327 \\
\hline Mid & 6 & 34 & 20 & 432 \\
\hline Lower & 2 & 8 & 1 & 99 \\
\hline$\%$ & 1.35 & 35.40 & 21.32 & 84.87 \\
\hline \multicolumn{5}{|c|}{ Clay lumps } \\
\hline Upper & 0 & 5 & 1 & 12 \\
\hline Mid & 0 & 5 & 1 & 48 \\
\hline Lower & 0 & 0 & 0 & 14 \\
\hline$\%$ & 0 & 0.86 & 0.74 & 7.32 \\
\hline \multicolumn{5}{|c|}{ Grinding s. } \\
\hline Upper & 2 & 4 & 11 & 0 \\
\hline Mid & 3 & 2 & 6 & 1 \\
\hline Lower & 0 & 0 & 1 & 0 \\
\hline$\%$ & 0.67 & 0.52 & 6.62 & 0.10 \\
\hline \multicolumn{5}{|l|}{ Palettes } \\
\hline Upper & 0 & 1 & 1 & 1 \\
\hline Mid & 0 & 1 & 0 & 0 \\
\hline Lower & 0 & 0 & 0 & 0 \\
\hline$\%$ & 0 & 0.17 & 0.37 & 0 \\
\hline
\end{tabular}

produce three different clusters, possibly suggesting three different types of aceramic microlithic assemblages. Unfortunately, the relatively low number of samples does not currently allow for a better investigation of this aspect. Furthermore, in order to refine the chronological, cultural, and economic settings of aceramic microlithic contexts, alternative proxies such as genetic faunal research and microplant remains have been recently applied (Chase et al. 2014b; García-Granero et al., 2016; respectively). In this context, the integration of physico-chemical proxies from surface and subsurface sediments can also provide new insights into the intensity and extension of past subsistence practices.

\subsection{Cultural soilscapes of North Gujarat}

The current study of dryland sediments at local scale explored a set of distinct sediment signatures within the archaeological landscape of North Gujarat. These signatures are the result of spatially and temporally variable geomorphic, pedogenic and cultural processes, all of them defining distinct cultural soilscapes (Wells, 2006). Cultural soilscapes represent an important analytical domain, yet not deeply explored in drylands, which can reveal the complex temporal relationships between soil bodies and the consequences of human behaviour. Two main classes of cultural soilscapes arise from this research: Late Pleistocene geogenic soil (vertisols and aridisols), and Holocene anthrosols (Fig. 15).

\subsubsection{Alluvial depositional environments: lower slope}

The physico-chemical clusters that characterise lower catena samples (i.e. clusters 4, 7 and 9 in section 5.2.4) are rich in organic matter, iron, silicate and metallic elements. These samples are all from clayish and silty vertisols of dark greyish colour (organic matter) and clayish texture that contributes to their shrink-swell potential. Vertisols are common in South Asia semi-arid moist regions, and in North Gujarat (where they are locally known as black cotton soils or goradu) are mostly found along the West Banas, Saraswati and $\mathrm{Ru}-$ pen river basins (Bhattacharyya et al., 2013; Khadkikar et al., 1999; Pal et al., 2009). They are the result of Holocene fluvially reworked aeolian silts, starting with the early Holocene more humid climate (Chamyal et al., 2003), and of pedogenised silty sand interdunal deposits (Juyal et al., 2006, 2003). Vertisols can be waterlogged for several months after the monsoon rains (Conesa et al., 2014) and are very suitable for cultivation. Moreover, they become excellent grazing fields after harvesting (Bhan, 2011). The concentration of clay, silt and organic matter characterising the lower catena physico-chemical clusters at the dune-interdune interface may reflect modern land use activities in the vertisols areas (such as crop residues and cattle grazing), as well as seasonal flooding. The presence of trace metallic elements in the studied vertisols can be related to either 1) present-day irrigation and atmospheric pollution (Aubert and Pinta, 1980; Fengxiang, 2007), and 2) intensive cash crop cultivation (e.g. Indian mustard), which have the ability to tolerate and accumulate $\mathrm{Pb}$, $\mathrm{Zn}, \mathrm{Ni}, \mathrm{Cr}$ and $\mathrm{Cu}$ (Ensley et al., 1997). Indeed, vertisols can be also described as agric horizons associated with modern crash-crop
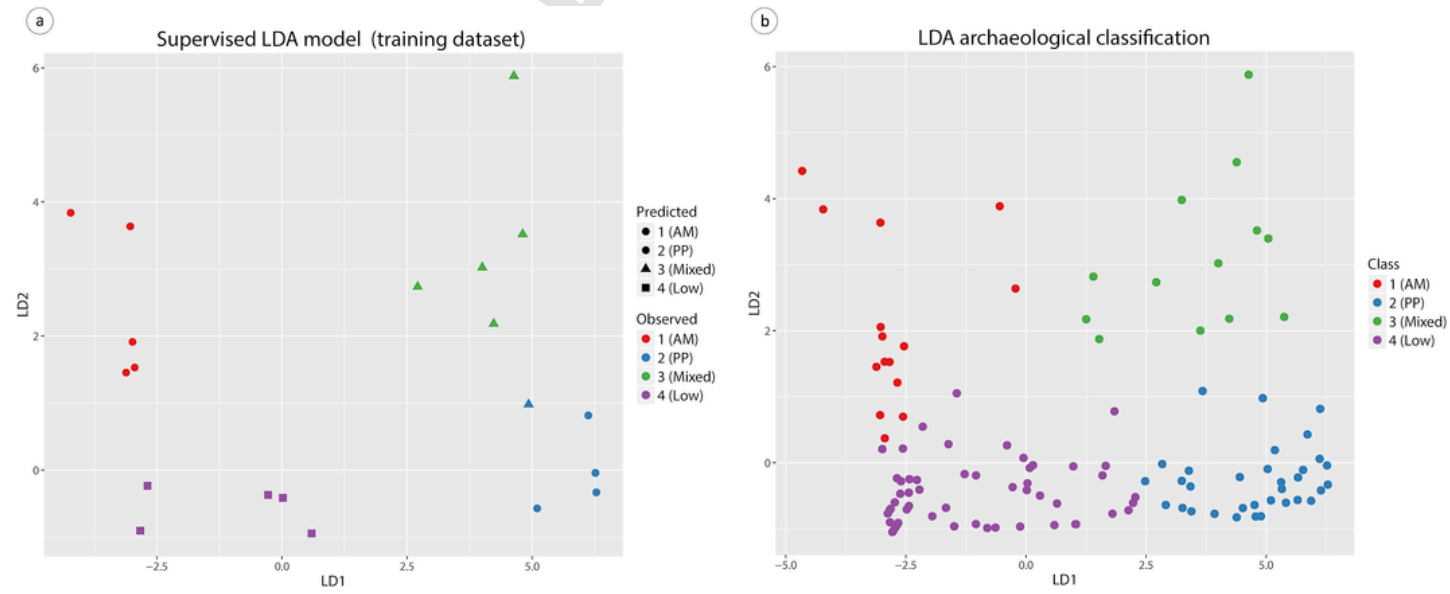

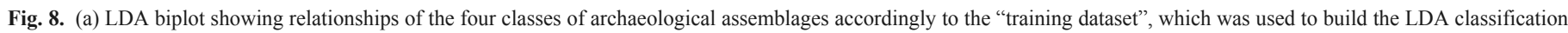
over the entire archaeological samples; (b) LDA biplot showing relationships for all predicted archaeological classes. 


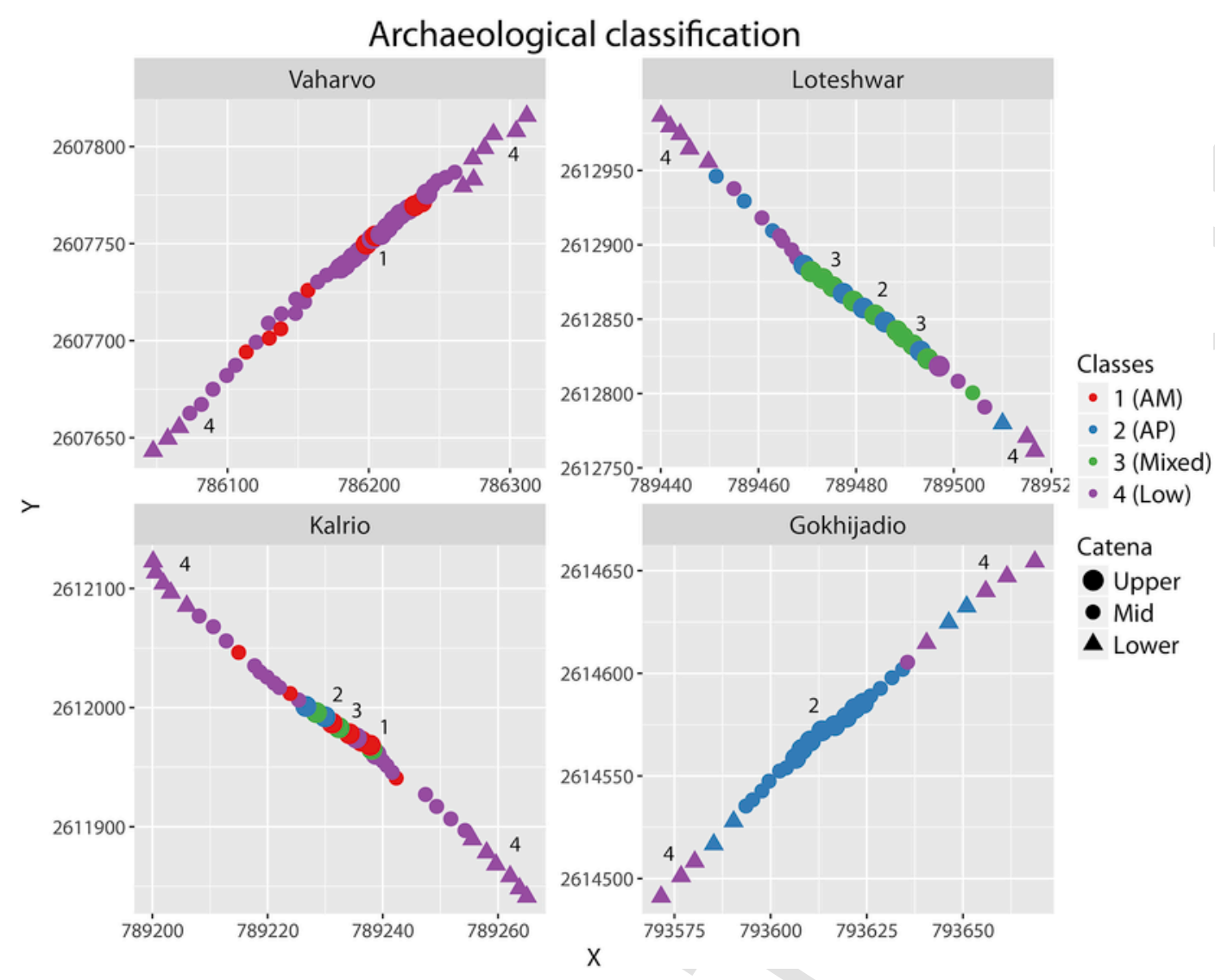

Fig. 9. Spatial distribution of the results from archaeological classification (LDA) displayed in a schematic representations of each sampling transect within the dune catena.

agriculture (Holliday, 2004), a key component of the economic wealth of North Gujarat (Dixit, 2009). Moreover, the seasonal flooding of vertisols has strongly structured settlement and mobility patterns in the region over time (Balbo et al., 2013, 2016; Salpeteur et al., 2015).

\subsubsection{Aeolian sand dune: mid-slope}

The physico-chemical signature that characterise samples in cluster 3 (abundant sand, high $\mathrm{Ca}$ carbonates content as described in section 5.2.4) is associated to a carbonate crust with cemented sand grains (locally known as kankar). This signature represents a geogenic aridisol originating from the aeolian sediments of late Pleistocene age. Current aeolian sediments (dunes) from the Thar Desert have similar contents of medium to fine sand $(1,82-2.65$ mean $\varphi)$ and calcium carbonates (Goudie et al., 1973; Hedge, 1977) with a superficial kankar crust. These mid-slope samples are associated with low evidence assemblages (Class 4 in section 4.4.2, Fig. 14) and fundamentally represent the original dune surface.

\subsubsection{Anthropic markers: upper slope and dune top}

Anthrosols are represented by aridisols showing different degrees of anthropic impact. In our analyses, each top dune is represented by a distinct physico-chemical cluster (as in section 4.2.4) identified as an anthrosol: cluster 1 at Vaharvo, cluster 2 at Kalrio cluster 5 at Gokhijadio and cluster 6 at Loteshwar (Fig. 13).

Our analyses show that the most significant anthropogenic indicator is the (high) concentration of $\mathrm{P}$ in samples from the upper portions of the dune. This pattern could be associated with present day farming practices, such as the use of manure as fertiliser or cattle grazing after the harvest (Holliday, 2004). The use of fertilisers in the dunes under study was not reported during oral interviews with the field owners, although it is worth mentioning that both Loteshwar and Gokhijadio were cultivated with castor oil after the monsoonal season, which may produce $\mathrm{P}$ enrichment due to cycles of plant uptake and organic residue decay. Some of the P content may have been fixed in soils by present day grazing activities. However, cattle pastures after the monsoonal rains are more focused on the exploitation of marshlands and interdunal vertisols rather than the top of fossilised dunes. Moreover, recent ethnoarchaeological studies on goat and cattle daily grazing in drylands (Elliot et al., 2014) detected higher amounts of $\mathrm{P}$ in soils ( $>5000 \mathrm{ppm}$ and $>11,000 \mathrm{ppm}$, respectively). These values are far from the highest concentrations in our samples. Furthermore, enrichment of $\mathrm{P}$ by orders of magnitude is only attested in the samples and clusters from the dune tops, in close correspondence with the areas showing high density of archaeological assemblages, whereas $\mathrm{P}$ concentrations in interdunal vertisols are found at low magnitudes. Therefore, the range and spatial distribution of $\mathrm{P}$ enrichment suggests a long-term fixation of anthropic $\mathrm{P}$ in soils as a result of different intensities of occupation.

In the CoA, mixed surface assemblages (Class 3 in section 4.4.2) correspond to the top of Loteshwar dune cluster 6 (as in section 5.2.4), which has the highest $\mathrm{P}$ concentrations. This correlates with the long human occupation recorded at Loteshwar, including hunter-gatherer and agropastoral communities over a 5000 years' time span, between 7168 and 2243 cal BC (García-Granero et al., 2016). In Loteswhar, the intensity of human occupation creates an interesting trade-off between $\mathrm{P}$ enrichment and $\mathrm{Ca}$ loosening. An increasing pattern of $\mathrm{Ca}$ and carbonates towards the dune top reflects the exposed aridisol of the fossilised sand dune. This signature is altered and diminished by the presence of a robust anthrosol at the top of the dune. 
Table 2

Mean values of physico-chemical proxies for each sampling transect along detailed catena units.

\begin{tabular}{|c|c|c|c|c|}
\hline & Vaharvo & Loteshwar & Kalrio & Gohkijadio \\
\hline \multicolumn{5}{|c|}{ Grain size (PSD $\varphi$ units) } \\
\hline Top & 1.97 & 2.10 & 1.37 & 1.38 \\
\hline Upper & 1.52 & 2.30 & 1.92 & 3.59 \\
\hline Mid-slope & 1.92 & 2.35 & 2.02 & 2.36 \\
\hline Lower mid-slope & 1.34 & 1.31 & 1.88 & 2.72 \\
\hline Foot & 1.81 & 1.94 & 1.94 & 2.49 \\
\hline Interdune & 1.54 & 3.05 & 2.22 & 3.09 \\
\hline \multicolumn{5}{|c|}{ Organic matter (LOI \%) } \\
\hline Top & 2.12 & 1.40 & 1.51 & 1.12 \\
\hline Upper & 1.60 & 1.20 & 1.00 & 1.15 \\
\hline Mid-slope & 1.71 & 0.89 & 0.91 & 1.13 \\
\hline Lower ms & 2.13 & 0.74 & 0.67 & 1.65 \\
\hline Foot & 3.36 & 0.71 & 0.78 & 1.33 \\
\hline Interdune & 4.06 & 1.00 & 1.01 & 1.01 \\
\hline \multicolumn{5}{|l|}{ Charcoal (LOI \&) } \\
\hline Top & 0.56 & 0.48 & 0.70 & 0.23 \\
\hline Upper & 0.66 & 0.51 & 0.71 & 0.24 \\
\hline Mid-slope & 0.50 & 0.58 & 0.55 & 0.20 \\
\hline Lower ms & 0.53 & 0.33 & 0.46 & 0.25 \\
\hline Foot & 0.46 & 0.44 & 0.53 & 0.23 \\
\hline Interdune & 0.48 & 0.39 & 0.63 & 0.21 \\
\hline \multicolumn{5}{|c|}{ Carbonates (LOI \%) } \\
\hline Top & 6.02 & 11.16 & 6.83 & 3.52 \\
\hline Upper & 5.53 & 8.20 & 9.43 & 3.22 \\
\hline Mid-slope & 5.56 & 6.45 & 6.03 & 1.92 \\
\hline Lower ms & 4.12 & 6.10 & 8.10 & 5.47 \\
\hline Foot & 3.63 & 3.33 & 3.62 & 0.70 \\
\hline Interdune & 3.07 & 3.69 & 1.99 & 5.47 \\
\hline \multicolumn{5}{|c|}{ Calcium (ICP-AES \%) } \\
\hline Top & 5.96 & 4.94 & 7.21 & 3.25 \\
\hline Upper & 5.28 & 7.95 & 6.72 & 2.91 \\
\hline Mid-slope & 5.28 & 6.44 & 6.17 & 1.85 \\
\hline Lower ms & 3.81 & 5.74 & 2.96 & 1.03 \\
\hline Foot & 3.34 & 4.07 & 1.80 & 0.33 \\
\hline Interdune & 2.37 & 2.91 & 1.88 & 0.20 \\
\hline \multicolumn{5}{|l|}{ Iron (ICP-AES \%) } \\
\hline Top & 0.68 & 0.88 & 0.62 & 0.87 \\
\hline Upper & 0.78 & 0.85 & 0.64 & 0.92 \\
\hline Mid-slope & 0.77 & 0.72 & 0.66 & 0.83 \\
\hline Lower ms & 0.70 & 0.64 & 0.63 & 0.94 \\
\hline Foot & 0.82 & 0.62 & 0.68 & 0.89 \\
\hline Interdune & 0.98 & 0.80 & 0.98 & 0.72 \\
\hline \multicolumn{5}{|c|}{ Phosphorus (ICP-AES ppm) } \\
\hline Top & 2305 & 2782 & 820 & 850 \\
\hline Upper & 1076 & 2427 & 962 & 1802 \\
\hline Mid-slope & 1168 & 810 & 530 & 1296 \\
\hline Lower ms & 467 & 622 & 445 & 704 \\
\hline Foot & 687 & 746 & 206 & 525 \\
\hline Interdune & 728 & 548 & 230 & 497 \\
\hline
\end{tabular}

The enrichment of $\mathrm{P}$ concentration towards the dune top is also noticed by the spatial distribution of cluster 5 (as in section 5.2.4), which is found at the CoA close to the abundance of potsherds, although $\mathrm{P}$ concentrations are lower than cluster 6 (mixed assemblages). In contrast, the top dune clusters 1 and 2 (Vaharvo dune top and Kalrio dune top in section 4.2.4) are close to aceramic microlithics and low evidence assemblages (classes 1 and 4 in section 4.4.2). These clusters have a relative low content of $\mathrm{P}$, suggesting little human footprints in hunter-gatherer occupations.

Several anthropic factors may also affect the aridisol signature, affecting dune erosion behaviour and the patterns of grain size distribution. Sparse vegetation cover and high basic erodibility of dominant sandy soils predispose the region to erosion by weathering. As a result, in the absence of anthropic activity, coarse sediments should concentrate on dune tops, whereas fine particles should be eluviated towards the interdune edges (Srivastava et al., 2001; Khadkikar,
2003). This sedimentary pattern is clearly attested in the clusters representing lower vertisols (finer clayish sediments), mid-slope aridisols (coarse sandy sediments) and top dune aceramic microlithics sediments (cluster 2 in section 4.2.4), as observed in Kalrio, and less strongly at Vaharvo (cluster 1 in section 5.2.4). In contrast to this trend, peaks of fine fractions of sediment are identified near the dune top at Loteshwar and Gokhijadio, characterising clusters 5 and 6 (as in section 5.2.4). Overall, samples from clusters with predominance of potsherds (class 2 in section 4.4.2) and samples from mixed scatters (class 3 in section 4.4.2) have higher concentrations of fine sediments (clay and silt particles) in comparison to sediments associated with aceramic microlithic assemblages. We interpret this accumulation of fine sediments on the top of dunes (attesting pastoral occupations) as the result of debris from vanished structures build with clay and silt collected in interdunal vertisols. Such structures as cooking platforms, floors and pit plastering are indeed attested in current pastoral ethnoarchaoelogical contexts in North Gujarat (Bhan, 2011; Rondelli et al., 2014). In archaeological contexts, malaxed clay balls and clay plastering are emblematic in Anarta and later pastoral contexts (Rajesh et al., 2013)

\subsection{Ongoing and further work}

Further research is needed to make extrapolations based on the significant but yet limited insights offered by the CoA and the definition of distinct types of anthrosols on the basis of the intensity of human occupations. In accordance, our ongoing work is addressing the reduction of the number of physico-chemical variables by selecting the most relevant ones under various criteria. The main aims of this step are reducing lab resources and simplify the statistical analyses. Furthermore, we are modelling the archaeological significance of sediment samples based on the selected physico-chemical variables.

While the physico-chemical variables have proven to be valuable because of their relationship to the archaeological variables within a soilscape context, the involved field and laboratory effort is considerable. Therefore, searching for similar relationships between archaeological variables and signals acquired by field and remote instruments would greatly facilitate archaeological work and allow for the intensive exploration of the spatial patterns of cultural soilscapes.

\section{Conclusions}

This paper used a set of analytical tools to put in evidence the relationship between surface archaeological assemblages and physico-chemical signatures within fossilised sand dunes. The joint analyses of archaeological and physico-chemical variables allowed us to understand the soilscapes of the area as follows:

- The dunes of North Gujarat have a distinct geogenic signature that corresponds to Late Quaternary aridisols, in close relation to the Quaternary sedimentation history of the area. These soilscapes are characterised by fine to coarse sandy sediments and high $\mathrm{Ca}$ and carbonates content.

- Interdunal areas are vertisols rich in clay, $\mathrm{Fe}, \mathrm{K}$ and $\mathrm{Ni}$ from accumulation of alluvial deposits and intense rainfed and irrigated agricultural practices.

- The footprint of aridisols is altered at the top of the dunes due to the presence of anthrosols characterising different degrees of human impact in sediment and soils.

- Agropastoral and mixed past occupations are characterised by high $\mathrm{P}$ content in sediment and soils. Fine sediment is also attested at the top of these dunes, suggesting potential remains of clay-related 


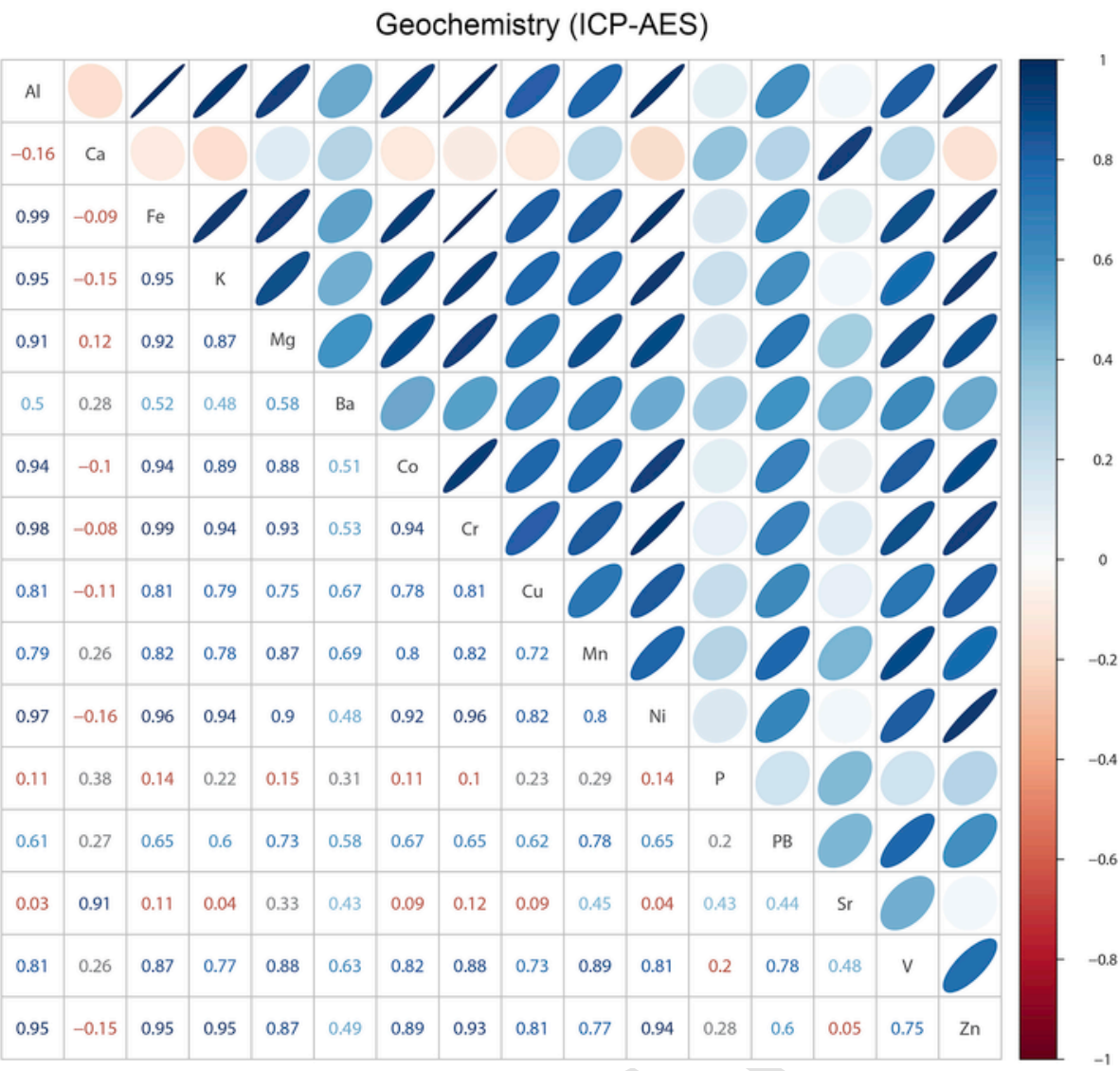

Fig. 10. Regression matrix of geochemistry concentrations (ICP-AES analysis).

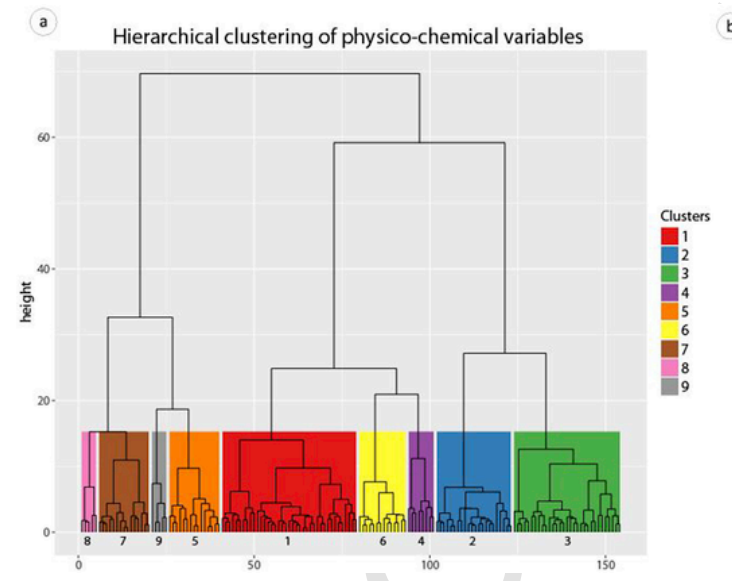

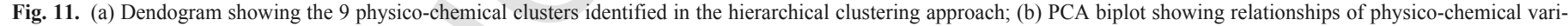
ables. Samples are labelled as the resulting physico-chemical clusters from the hierarchical clustering approach.

structures and activities and anthropic transport of fine sediment from near interdune deposits.

- Hunther-gatherer occupations are less intense in terms of potential anthropic markers (P content and fine sediments). They also leave a less visible type of surface distribution of artefacts, mainly composed by aceramic microlithic assemblages.

The quantification and distribution of archaeological assemblages can now be integrated within the depositional and post-depositional processes affecting relict aeolian surfaces. Moreover, this study represents an exploratory approach to understand settlement patterns at the local scale introducing physico-chemical proxies beyond archaeological artefacts. This approach offers a more comprehensive view of anthrosols within the cultural soilscape. The identification of the spatial distribution of soilscapes offers new insights to study Holocene surface scatters in drylands.

\section{Acknowledgements}

This research arises from collaboration between the MS University of Baroda and the IMF-CSIC (Spanish National Research Coun- 


\section{Hierarchical clustering}

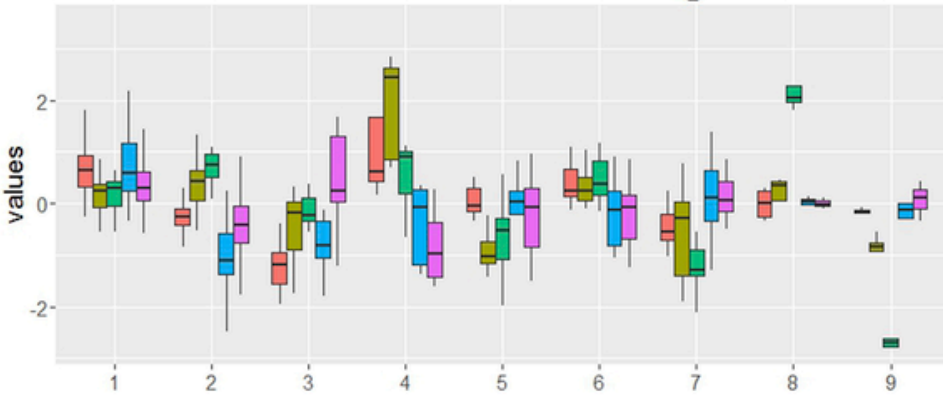

\section{Physical proxies}

Organic matter

官 Charcoal

Carbonates

Clay and silt

官 Sand

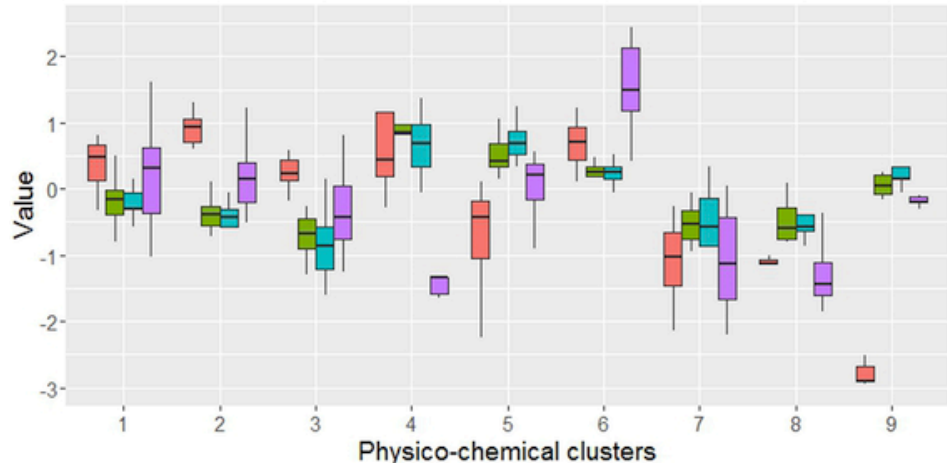

\section{Chemical proxies}

官 $\mathrm{K}$

追P

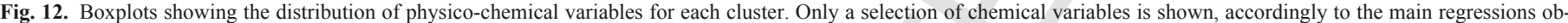
served in Fig. 10.

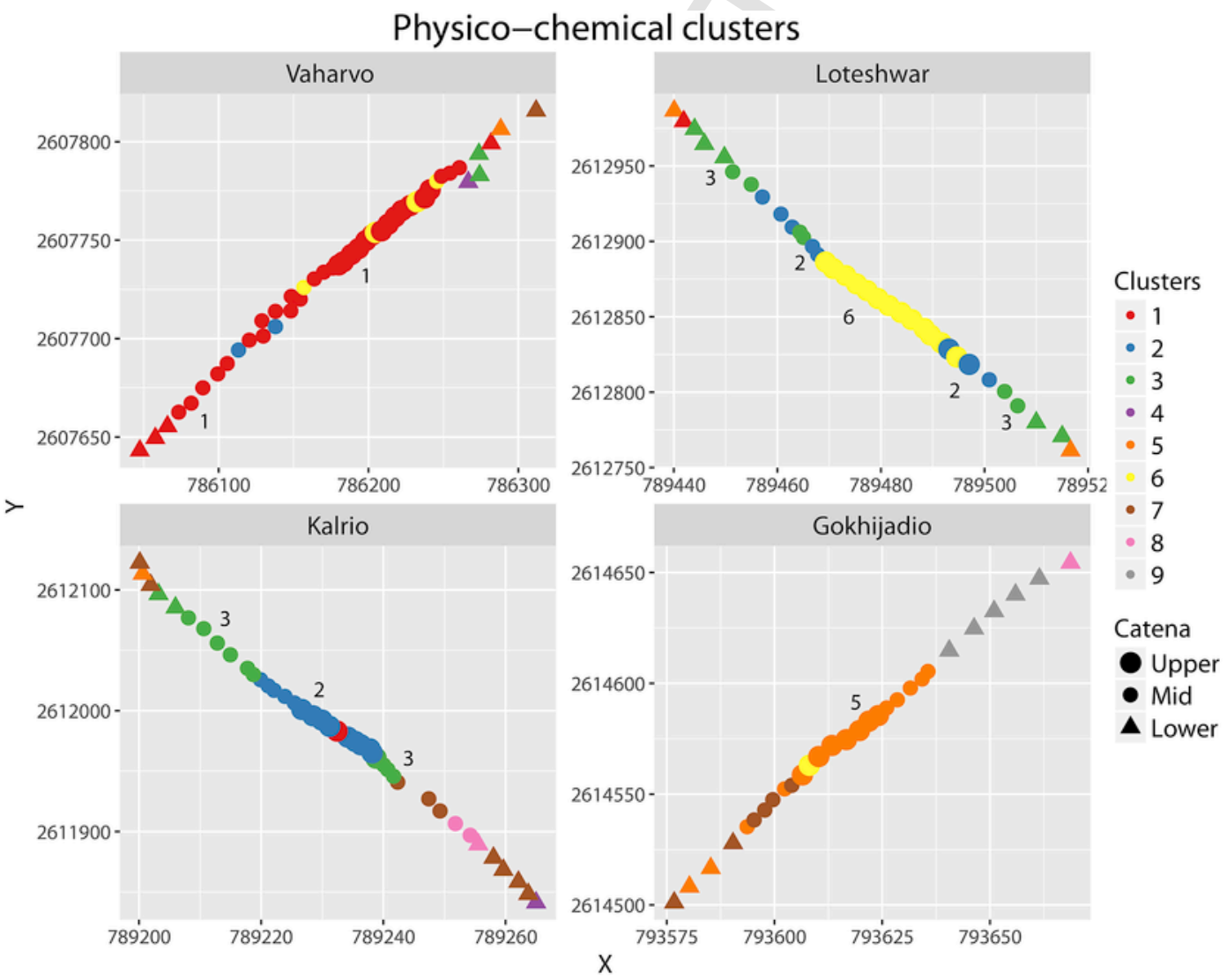

Fig. 13. Spatial distribution of the hierarchical physico-chemical clusters displayed in a schematic representations of each sampling transect within the dune catena. 
Table 3

Contingency table between the results of the archaeological classification and the hierarchical physico-chemical clusters.

Physico-chemical clusters

$\begin{array}{lllllllll}1 & 2 & 3 & 4 & 5 & 6 & 7 & 8 & 9\end{array}$

Archaeological classes

Aceramic microlithic

Predominance of pottery

Mixed assemblages

Low evidence

cil) within the framework of the North Gujarat Archaeological Project (NoGAP) and the SimulPast Project (CSD2010-00034). F.C. Conesa acknowledges worked on this paper with funding from the JAE-PreDoc program (CSIC and European Social Found). A. L.
Balbo worked on this paper under the Juan de la Cierva Programme (MINECO JCI-2011-10734), and with a Research Fellowship from the Alexander von Humboldt Foundation/Stiftung. FC wishes to thank M. Guart and P. Povea from the Laboratori de Sedimentologia, Departament d'Estratigrafia, Paleontologia i Geosciències Marines, Facultat de Geologia, Universitat de Barcelona, where part of the physico-chemical analyses was carried out. The authors wish to thank R. Julià for his comments on soil geochemical patterns and S. Markofsky, N. Égüez and the anonymous reviewers for their valuable comments on the original manuscript.

\section{Appendix A. Supplementary data}

Supplementary data related to this article can be found at http://dx. doi.org/10.1016/j.quaint.2016.11.013.

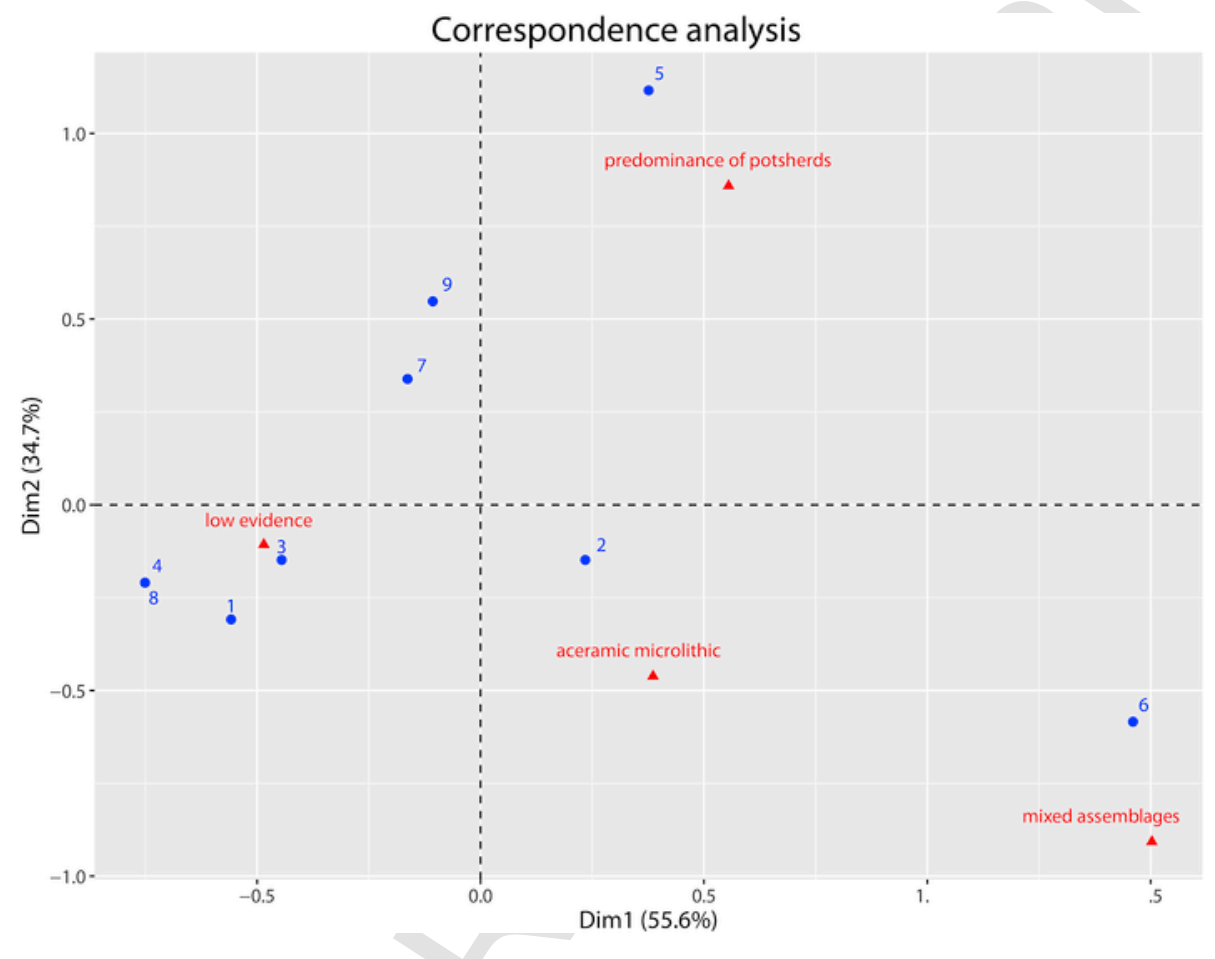

Fig. 14. Correspondence analysis showing contingencies between archaeological classes and physico-chemical clusters. 

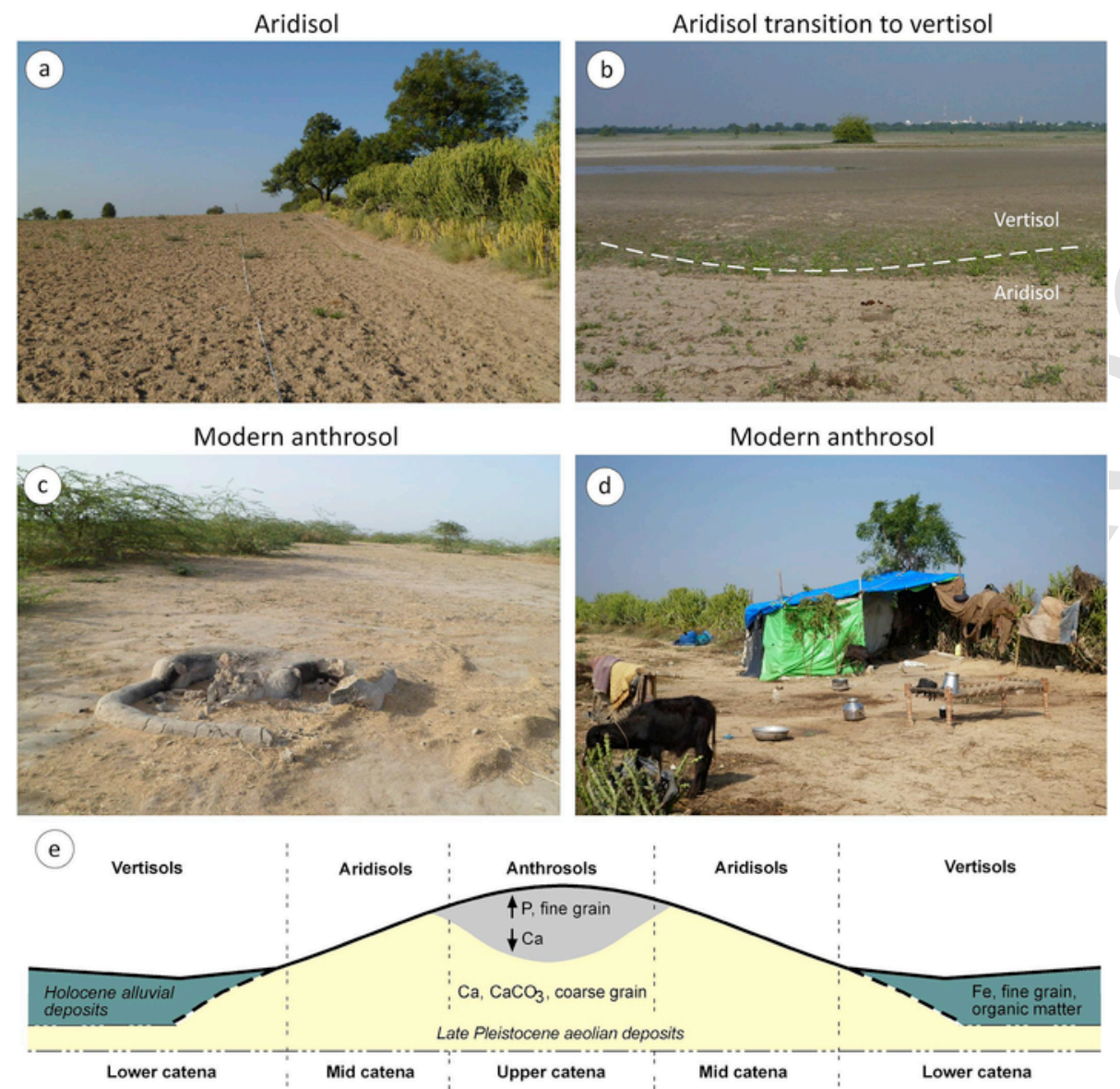

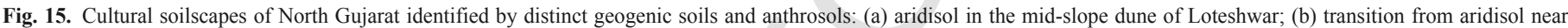

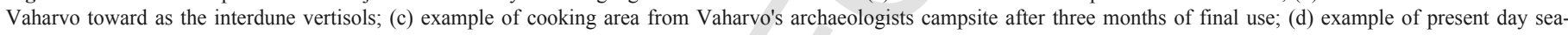

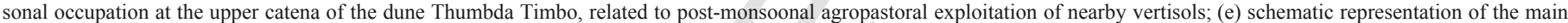
physico-chemical patterns for the proposed geogenic and anthropic soilscapes.

\section{References}

Ajithprasad, P., 2004. Holocene adaptations of the mesolithic and chalcolithic settlements in North Gujarat. In: Yasuda, Y., Shinde, V. (Eds.), Monsoon and Civilizations. Roli Books, New Delhi, pp. 115-132.

Ajithprasad, P., 2011. Chalcolithic cultural patterns and the early harappan interaction in Gujarat. In: Osada, T., Witzel, M. (Eds.), Cultural Relations between the Indus and the Iranian Plateau during the Third Millennium BCE. Harvard Oriental Series, Cambridge, pp. 11-42.

Ajithprasad, P., Sonawane, V.H., 2011. The harappa culture in North Gujarat: a regional paradigm. In: Osada, T., Uesugi, A. (Eds.), Linguistics, Archaeology and the Human Past. Research Institute for Humanity and Nature, Kyoto, pp. 223-269.

Allen, H., Holdaway, S., Fanning, P., Littleton, J., 2008. Footprints in the sand: appraising the archaeology of the Willandra Lakes, western new south Wales, Australia. Antiquity 82, 11-24.

Aubert, H., Pinta, M., 1980. Trace Elements in Soils. Elsevier, New York.

Balbo, A.L., Rondelli, B., Conesa, F.C., Lancelotti, C., Madella, M., Ajithprasad, P., 2013. Contributions of geoarchaeology and remote sensing to the study of Holocene hunter-gatherer and agro-pastoral groups in arid margins: the case of North Gujarat (Northwest India). Quat. Int. 308-309, 53-65.

Balbo, A.L., Cabanes, D., García-Granero, J.J., Bonet, A., Ajithprasad, P., Terradas, X., 2015. A microarchaeological approach for the study of pits. Environ. Archaeol. 20 (4), 390-405.

Balbo, A.L., Gómez-Baggethun, E., Salpeteur, M., Puy, A., Biagetti, S., Scheffran, J., 2016. Resilience of small-scale societies. A view from drylands. Ecol. Soc. 21 (2), $1-23$

Bayón, C., Frontini, R., Vecchi, R., 2012. Middle Holocene settlements on coastal dunes, southwest Buenos aires province, Argentina. Quat. Int. 256, 54-61.
Beach, N., Dunning, M., Doyl, M., 2008. Geoarchaeology and geomorphology: soils, sediments, and societies. Quat. Int. 101, 3.

Bevan, A., Wilson, A., 2013. Models of settlement hierarchy based on partial evidence. J. Archaeol. Sci. 40, 2415-2427.

Bevan, A., Crema, E., Li, X., Palmisano, A., 2013. Intensities, interactions and uncertainties: some new approaches to archaeological distributions. In: Bevan, A., Lake, M. (Eds.), Computational Approaches to Archaeological Spaces. Left Coast Press, Walnut Creek.

Bhan, K.K., 1994. Cultural development of the prehistoric period in North Gujarat with reference to Western India. J. South Asian Stud. 10, 71-90.

Bhan, K.K., 2011. Pastoralism in Late Harappan Gujarat, western India: an ethnoarchaeological approach. In: Osada, T., Uesugi, A. (Eds.), Linguistics, Archaeology and the Human Past. Research Institute for Humanity and Nature, Kyoto, pp. 1-27.

Bhattacharyya, T., Pal, D.K., Mandal, C., Chandran, P., Ray, S.K., Sarkar, D., Velmourougane, K., Srivastava, A., Sidhu, G.S., Singh, R.S., Sahoo, A.K., Dutta, D., Nair, K.M., Srivastava, R., Tiwary, P., Nagar, A.P., Nimkhedkar, S.S., 2013. Soils of India: historical perspective, classification and recent advances. Curr. Sci. 104, 1308-1323.

Blau, S., Denham, T., Magee, P., Biggins, A., Robinson, J., Jasim, S., 2008. Seeing through the dunes: geophysical investigations at muweilah, an iron age site in the United Arab Emirates. J. Field Archaeol. 27 (2), 117-129.

Brantingham, P.J., Surovell, T., Waguespack, N.M., 2007. Modeling post-depositional mixing of archaeological deposits. J. Anthropol. Archaeol. 26, 517-540.

Burger, O., Todd, L.C., Burnett, P., Stohlgren, J., Stephens, D., 2002. Multi -scale and nested- intensity sampling techniques for archaeological survey. J. Field Archaeol. 29, 409-423.

Calegari, M.R., Madella, M., Vidal-Torrado, P., Pessenda, L.C.R., Marques, F.A., 2013. Combining phytoliths and $\delta 13 \mathrm{C}$ matter in Holocene palaeoenvironmental studies of tropical soils: an example of an Oxisol in Brazil. Quat. Int. 287, 47-55. 
Chamyal, L.S., Maurya, D.M., Raj, R., 2003. Fluvial systems of the drylands of western India: a synthesis of Late Quaternary environmental and tectonic changes. Quat. Int. 104, 69-86.

Chase, B., Ajithprasad, P., Rajesh, S.V., Patel, A., Sharma, B., 2014. Materializing harappan identities: unity and diversity in the borderlands of the Indus civilization J. Anthropol. Archaeol. 35, 63-78.

Conesa, F.C., Devanthéry, N., Balbo, A.L., Madella, M., Montserrat, O., 2014. Use of satellite SAR for understanding long-term human occupation dynamics in the monsoonal semi-arid plains of North Gujarat, India. Remote Sens. 6, 11420-11443.

Conesa, F.C., Madella, M., Galiatsatos, N., Balbo, A.L., Rajesh, S.V., Ajithprasad, P., 2015. CORONA photographs in monsoonal semi-arid environments: addressing archaeological surveys and historic landscape dynamics over North Gujarat, India. Archaeol. Prospect. 22, 75-90.

Deo, S.G., Ghate, S., Rajaguru, S.N., 2011. Holocene environmental changes and cultural patterns in coastal western India: a geoarchaeological perspective. Quat. Int. 229, 132-139.

Dirix, K., Muchez, P., Degryse, P., Mu, B., Poblome, J., 2013a. Integrating multi-element geochemical and magnetic survey at ancient sagalassos (southwest Turkey): anthropogenic versus natural anomalies. Archaeol. Prospect. 20 (4), 233-247.

Dirix, K., Muchez, P., Degryse, P., Mu, B., 2013b. Integrating Geochemical Survey and Magnetic Prospection on an Archaeological Site in SW-Turkey. EGU General Assembly 2013, Publication 4/2013.

Dixit, A.K., 2009. Agriculture in a high growth state: case of Gujarat (1960 to 2006) Econ. Political Wkly. 69, 64-71.

Elliot, S., Bendrey, R., Whitlam, J., Rauf, K., 2014. Preliminary ethnoarchaeological research on modern animal husbandry in Bestansur, Iraqi Kurdistan: integrating animal, plant and environmental data. Environ. Archaeol. 20 (3), 283-303.

Ensley, B., Raskin, I., Salt, D.E., 1997. Phytoremediation applications for removing heavy metal contamination from soil and water. In: Sayler, G.S., Sanseverino, J. Davis, K. (Eds.), Biotechnology in the Sustainable Environment. Springer, New York, pp. 59-64.

Fanning, P.C., Holdaway, S.J., Rhodes, E.J., 2007. A geomorphic framework for understanding the surface archaeological record in arid environments. Geodin. Acta 20, 275-286.

Fanning, P.C., Holdaway, S.J., 2001. Artefact visibility at open sites in Western new south Wales, Australia. J. Field Archaeol. 20 (3), 255-271.

Fengxiang, X.H., 2007. Biogeochemistry of Trace Elements in Arid Environments. Springer, New York.

Fernández-López de Pablo, J., Barton, C.M., 2015. Bayesian estimation dating of lithic surface collections. J. Archaeol. Method Theory 22 (2), 1-25.

French, C., Sulas, F., Petrie, C., 2014. Expanding the research parameters of geoarchaeology: case studies from Aksum in Ethiopia and Haryana in India. Archaeol. Anthropol. Sci. 1, 1-14.

Gadekar, C., Ajithprasad, P., Madella, M., Balbo, A.B., Rajesh, S.V., Rondelli, B., Garcia-Granero, J.J., Rodriguez Antón, D., Yannitto, V., 2014. Continuation of a tradition over five thousand years: lithic assemblage from Loteshwar, North Gujarat, Western India. Herit. J. Multidiscip. Stud. Archaeol. 2, 283-304.

Gallant, T.W., 1986. "Background noise" and site definition: a contribution to survey methodology. J. Field Archaeol. 13, 403-418.

García-Granero, J.J., Lancelotti, C., Madella, M., 2015. A tale of multi-proxies: integrating macro- and microbotanical remains to understand subsistence strategies. Veg. Hist. Archaeobotany 24 (1), 121-133.

García-Granero, J.J., Lancelotti, C., Madella, M., Ajithprasad, P., 2016. Millets and herders: the origins of plant cultivation in semi-arid North Gujarat (India). Curr. Anthropol. 57 (2), 149-166.

Goldberg, P., Macphail, R., 2006. Practical and Theoretical Geoarchaeology. Blackwell Publishing, Oxford.

Goodman-Elgar, M. 2008. The devolution of mudbrick: ethnoarchaeology of abandoned earthen dwellings in the Bolivian Andes, J. Archaeol. Sci. 35: 3057-3071. Goudie, A., Allchin, B., Hegde, K.T.M., 1973. The former extensions of the great indian sand Desert. Geogr. J. 139, 243-257.

Goudie, A., 2002. Great Warm Deserts of the World: Landscapes and Evolution. Oxford University Press.

Greenacre, M.J., 2007. Correspondence Analysis in Practice. Chapman \& Hall, New York.

Hedge, K.T.M., 1977. Late quaternary environments in Gujarat and Rajasthan. In: Agrawal, D.P., Pande, B.M. (Eds.), Ecology and Archaeology of Western India. Naurang Rai, Anand Nagar. pp. 169-180.

Heiri, O., Lotter, A.F., Lemcke, G., 2001. Loss on ignition as a method for estimating organic and carbonate content in sediments: reproducibility and comparability of results. J. Paleolimnol. 25, 101-110.

Holliday, V.T., 2004. Soils in Archaeological Research. Oxford University Press, Oxford.
Holliday, V.T., Gartner, W.G., 2007. Methods of soil P analysis in archaeology. J. Archaeol. Sci. 34, 301-333.

James, G., Witten, D., Hastie, R., Tibshirani, T., 2013. An Introduction to Statistical Learning with Applications in R. Springer Texts in Statistics. (New York).

Jennings, R.P., Shipton, C., Breeze, P., Cuthbertson, P., Antonio, M., Wedage, W.M.C.O., Drake, N.A., White, T.S., Groucutt, H.S., Parton, A., et al., 382, 24 September 2015, 58-81. Multi-scale acheulean landscape survey in the arabian Desert. Quat. Int.

Juyal, N., Kar, A., Rajaguru, S.N.N., Singhvi, A.K., 2003. Luminescence chronology of aeolian deposition during the Late Quaternary on the southern margin of Thar Desert, India. Quat. Int. 104, 87-98.

Juyal, N., Chamyal, L.S., Bhandari, S., Bhushan, R., Singhvi, A.K., 2006. Continenta record of the southwest monsoon during the last 130ka: evidence from the southern margin of the Thar Desert, India. Quat. Sci. Rev. 25, 2632-2650.

Kantner, J., 2008. The archaeology of regions: from discrete analytical toolkit to ubiquitous spatial perspective. J. Archaeol. Res. 16, 37-81.

Khadkikar, A.S., Mathew, G., Malik, J.N., Gundu Rao, T.K., Chowgaonkar, M.P., Merh, S.S., 1999. The influence of the South-west Indian monsoon on continental deposition over the past $130 \mathrm{kyr}$, Gujarat, western India. Terra nova. 11, 273-277.

Khadkikar, A.S., 2003. Bedform migration and bar evolution in a late Quaternary monsoon-influenced river, Gujarat, western India. Sediment. Geol. 157, 277-289.

Kluiving, S., van Mourik, J.M., Barbante, C., Zaccone, C. (Eds.), 2013. Soils as a Record of the Past. Quaternary International 306.

Krumbein, W.C., 1938. Size frequency distribution of sediments and the normal phi curve. J. Sediment. Petrology 8, 84-90.

Madella, M., Ajithprasad, P., Balbo, A.L., Caro, J., Conesa, F.C., Garcia-Granero, J.J., Lancelotti, C., Rondelli, B., Rajesh, S.V., Ruiz, J., Mateos, J.L., Gadekar, G.S., Kothyari, G.C., Mortekhai, P., Sukumaran, P., 2012. La campaña de excavación 2011 del North Gujarat Archaeological Project (NoGAP): metodología interdisciplinar para el estudio de contextos socio-ecológicos en el Holoceno. In: Informes y Trabajos. Excavaciones en el Exterior 2011. Ministerio de Educación, Cultura y Deporte, pp. 261-272.

Mallol, C., Bertran, P., 2010. Geoarchaeology and taphonomy. Quat. Int. 214, 1-2.

Markofsky, S., Ninfo, A., Balbo, A., Conesa, F.C., Madella, M., 2016. An investigation of local scale human/landscape dynamics in the endorheic alluvial fan of the Murghab River, Turkmenistan. Quat. Int. 1-19.

Middleton, W.D., Price, D.T., 1996. Identification of activity areas by multi-element characterization of sediments from modern and archaeological house floors using inductively coupled plasma-atomic emission spectroscopy. J. Archaeol. Sci. 23, 673-687.

Milligan, G.W., Cooper, M.C., 1985. An examination of procedures for determining the number of clusters in a data set. Psychometrika 50, 159-179.

Mojena, R., 1977. Hierarchical grouping methods and stopping rules: an evaluation. Comput. J. 20, 359-363.

Mushrif-Tripathy, V., Ajithprasad, P., Madella, M., Mateos, J.L., Rajesh, S.V., Rondelli, B., Caro Saiz, J., Lancelotti, C., Gadekar, C.S., Garcia-Granero, J.J., 2014. Osteological study of a human skeleton excavated from Vaharvo Timbo, district patan, Gujarat. Man Environ. 39 (1), 46-51.

Nielsen, N.H., Kristiansen, S.M., 2014. Identifying ancient manuring: traditional phosphate vs. multi-element analysis of archaeological soil. J. Archaeol. Sci. 42, 390-398.

Pal, D.K., Dasog, G.S., Bhattacharyya, T., 2009. Pedogenetic processes in cracking clay soils (vertisols) in tropical environments of India: a critique. J. Indian Soc. Soil Sci. 57, 422-432.

Patel, A.K., 2009. Occupational histories, settlements, and subsistence in Western India: what bones and genes can tell us about the origins and spread of pastoralism. Anthropozoologica 44, 173-188.

Puy, A., Balbo, A.L., 2013. The genesis of irrigated terraces in al-Andalus. A geoarchaeological perspective on intensive agriculture in semi-arid environments (Ricote, Murcia, Spain). J. Arid Environ. 89, 45-56.

Puy, A., Balbo, A.L., Virgili, A., Kirchner, H., 2014. The evolution of Mediterranean wetlands in the first millennium AD: the case of Les Arenes floodplain (Tortosa, NE Spain). Geoderma 232-234, 219-235.

Raj, R., Chamyal, L.S., Prasad, V., Sharma, A., Tripathi, J.K., Verma, P., 2015. Holocene climatic fluctuations in the Gujarat Alluvial Plains based on a multiproxy study of the Pariyaj Lake archive, western India. Palaeogeogr. Palaeoclimatol. Palaeoecol. 421, 60-74.

Rajesh, S.V., Krishnan, K., Ajithprasad, P., Sonawane, V.H., 2013. Evaluating the Anarta tradition in the light of material culture from Loteshwar and other sites in Gujarat. Man Environ. 38, 10-45.

Rajesh, S.V., Krishnan, K., 2014. Chalcolithic Cultures of Gujarat (c. 3950-900 BCE): an appraisal. In: Mani, B.R., Singhvi, A.K., Kumar, R. (Eds.), Pracyabodha. Indian Archaeology and Tradition. B. R. Publishing, New Delhi, pp. 194-205.

R-Core-Team, 2014. R: a Language and Environment for Statistical Computing. 
Read, D.W., 1986. Sampling procedures for regional surveys: a problem of effectiveness and representativeness. J. Field Archaeol. 13, 477-491.

Rondelli, B., Lancelotti, C., Madella, M., Pecci, A., Balbo, A., Perez, J.R., Inserra, F., Gadekar, C., Cau, M.A., Ajithprasad, P., 2014. Anthropic activity markers and spatial variability: an ethnoarchaeological experiment in a domestic unit of Northern Gujarat (India). J. Archaeol. Sci. 41, 482-492.

Salisbury, R.B., Bertók, G., Bácsmegi, G., 2013. Integrated prospection methods to define small-site settlement structure: a case study from neolithic Hungary. Archaeol. Prospect. 20, 1-10.

Salpeteur, A.M., Patel, H., Balbo, A.L., Madella, M., Ajithprasad, P., 2015. Kin groups and the distribution of traditional ecological knowledge in a community of seminomadic pastoralists. Gujarat (India) Curr. Anthropol. 56 (3), 471-483.

Sedov, S., Jacobs, P., 2012. Paleosols in soilscapes of the past and present. Quat. Int. 265.

Shah, T., 2014. Towards a Managed Aquifer Recharge Strategy for Gujarat, India: an economist's dialogue with hydro-geologists. J. Hydrology 518, 94-107.

Shahack-gross, R., Marshall, F., Weiner, S., 2003. Geo-ethnoarchaeology of pastora sites: the identification of livestock enclosures in abandoned Maasai settlements. J. Archaeol. Sci. 30, 439-459.

Shennan, S., 2004. Quantifying Archaeology. Edinburgh University Press.

Singhvi, A.K., Kar, A., 2004. The aeolian sedimentation record of the Thar Desert. Proc. Indian Acad. Sci. 113, 371-401.

Singhvi, A.K., Williams, M.J., Rajaguru, S.N., Misra, V.N., Chawla, S., Stokes, S., Chauhan, N., Francis, T., Ganjoo, R.K., Humphreys, G.S., 2010. A 200 ka record of climatic change and dune activity in the Thar Desert, India. Quat. Sci. Rev. 29, 3095.

Sjöberg, A., 1976. Phosphate analysis of anthropic soils. J. Field Archaeol. 3, 447-454. Sonawane, V.H., 2000. Early Farming Communities of Gujarat, India. Indo-Pacific Prehistory Association Bulletin 19, 137-146.
Srivastava, P., Juyal, N., Singhvi, A.K., Wasson, R.J., Bateman, M.D., 2001. Luminescence chronology of river adjustment and incision of Quaternary sediments in the alluvial plain of the Sabarmati River, north Gujarat, India. Geomorphology $36,217-229$.

Tainter, J., 1979. The mountainair lithic scatters: settlement patterns and significance evaluation of low density surface sites. J. Field Archaeol. 6, 463-469.

Wandsnider, L., Camilli, E.L., 1992. The character of surface archaeological deposits and its influence on survey accuracy. J. Field Archaeol. 19, 169-188.

Wells, E.C., 2006. Cultural soilscapes. In: Frossard, E., Blum, W.E.H., Warkentin, B.P. (Eds.), Function of Soils for Human Societies and the Environment. pp. 125-132. London.

Wilson, C., Davidson, D., Cresser, M.S., 2008. Multi-element soil analysis: an assessment of its potential as an aid to archaeological interpretation. J. Archaeol. Sci. 35, 412-424. Wilson, L., 2013. The role of geoarchaeology in extending our perspective, in: Wilson, L. (Ed.), Human Interactions with the Geosphere: The Geoarchaeological Perspective. Geological Society, London, pp. 1-9.

Wright, V., 1991. Calcretes: an introduction. In: Wright, V., E, T.M. (Eds.), Calcretes. Blackwell Scientific Publications, Oxford, pp. 1-22.

Zerboni A., Bernasconi A., M. Cremaschi M., (2013). 9. Micromorphological study of living floors and mud features from the excavation of Fewet. Mori L., (Eds.), Life and Death of a Rural Village in Garamantian Times. Archaeological Investigations in the Fewet oasis (Libyan Sahara). Arid Zone Archaeology Monographs, 6, Edizioni all'Insegna del Giglio, Firenze, 119-138. 